\title{
O intérprete negro na história da tradução oral: da tradição africana ao colonialismo português no Brasil
}

Dennys Silva-Reis*

\section{Prólogo}

A história da interpretação no Brasil é um campo que vem despertando interesse de pesquisadores brasileiros e estrangeiros ${ }^{1}$, apesar de ainda se mostrar tímida na área nacional dos Estudos de Tradução². Michael Cronin (2002) em seu ensaio “The Empire Talks Back: Orality, Heteronomy, and the Cultural Turn in Interpreting Studies" menciona que existem ainda dois grandes problemas nos Estudos de Interpretação: 1) de que maneira a passagem à forma quirográfica e tipográfica afetou a tradução (escrita e oral) em si; e 2) a não-consideração da existência de grupos sociais em que a forma oral é (ou foi) extremamente mais importante (ou até mesmo a única) em relação à forma escrita. Em suma, o que Cronin alega é que os

\footnotetext{
* Dennys Silva-Reis é doutorando em Literatura (POSLIT) e mestre em Estudos da Tradução (POSTRAD) pela Universidade de Brasília (UnB). É professor de Língua e Literatura francesas, tradutor e cronista.

${ }^{1}$ Ver: ALMEIDA, 2012, 2014.; BARROS, MARUYAMA, 2007. BARROS, 1994, 2011; CARVALHO, 2012, 2015; DELISLE, 1977; JULIO, 2015; MARIANI, 2007; METCALF, 2005, 2009a, 2009b; OLIVEIRA, 2005, 2006; PERRONE-MOISÉS, 2013; PINHEIRO, 2005, 2008; SANTOS, 2008.

2 Dentro do escopo de pesquisadores dos Estudos da Tradução no Brasil, podemos mencionar os seguintes trabalhos sobre história da interpretação: CAMPBELL, 1984; GINEZI, 2012; MARTINS, 2007, ORIGUELA, 2014, PAGURA, 2010, 2012; PRATA, 2017. QUEIROZ, 2011, 2014; ROMÃO, 1998; SILVA, 2013, 2014; SILVA-REIS, BAGNO, 2016; WYLER, 2003. Há também apenas três trabalhos que compreendem parte de uma historiografia da tímida institucionalização dos Estudos da Interpretação no Brasil: BARBOSA, 2009; CAVALLO, REUILLARD, 2016; e GUERINI, COSTA, TORRES, 2013.
} 
estudos de interpretação ainda não deram importância suficiente à sua matéria prima: a oralidade - seja como técnica de comunicação, seja como base de comunidades essencialmente orais.

Esses dois dados estão intimamente ligados à problemática da escrita historiográfica, pois, de um lado, a história até aqui construída tem por fontes essenciais a materialidade escrita - em línguas hegemônicas e por autores, em certa medida, "detentores de poder" (escrivães, cronistas, naturalistas, dentre outros a mando de países imperialistas ou colonizadores) - ; por outro lado, grupos sociais orais (em particular os ágrafos) ou existentes "somente na oralidade" (relatos, contos, lendas, mitos, etc.) ainda carecem de uma historiografia. No Brasil, por exemplo, o interesse pela história e literatura indígenas vem trazendo à tona cada vez mais as textualidades indígenas ${ }^{3}$, o que só confirma a permanência do paradigma da cultura escrita, bem como o interesse cada vez mais latente por essas culturas ágrafas.

No que concerne, em particular, à história da interpretação, um grupo de intérpretes recebeu ainda poucos estudos: os negros. No conhecido capítulo "Os intépretes que fizeram história" escrito por Margereta Bowen, David Bowen, Francine Kaufmann e Ingrid Kurz na obra Os tradutores na história (1998), organizado por Jean Delisle e Judith Woodsworth, apenas dois parágrafos são dedicados aos intérpretes negros africanos. Jean Delisle (1993, 1977, 1999, 2005) em nenhum de seus trabalhos, mesmo o mais extenso e mais completo (DELISLE, 1987), dedicados à história dos intérpretes no Canadá, menciona a importante figura de Mathieu da Costa ${ }^{4}$ intérprete negro que auxiliou na colonização do Canadá, notadamente por trabalhar na expedição de Samuel Champlain (1606).

Mesmo que os mais conhecidos historiadores da tradução não tenham dado a devida atenção a este grupo étnico de intérpretes, alguns trabalhos são inovadores por trazerem à tona este aspecto da história da interpretação: "History and Role of Interpreting in Africa" de Anna Niang

\footnotetext{
${ }^{3}$ Sobre o assunto: MATOS, 2012.

${ }^{4}$ Mais informações em http://www.thecanadianencyclopedia.ca/en/article/mathieu-da-costa/. Acesso em 14 de julho de 2017.
} 
(1990); "A history of translation and interpretation in Cameroon from precolonial times to present" de Charles Atanganna Nama (1990), Intermediaries, Interpreters, and Clerks. African Employees in the Making of Colonial Africa, organizado por Benjamin N. Lawrance, Emily Lynn Osborn e Richard L. Roberts (2006) e "The Invisibility of the African Interpreter" de Jeanne Garane (2015).

É perceptível que todos os trabalhos citados no parágrafo anterior se referem ao intérprete negro africano. Entretanto, como é sabido, o número de negros que foram dispersados nos outros continentes para além do africano é enorme. E apesar de sabermos que tal dispersão se deu majoritariamente pela escravidão, os negros escravizados foram estratificados socialmente e historicamente pelos diversos ofícios que exerciam, dentre eles o de intérprete. A história desses intérpretes negros da diáspora ainda é pouco conhecida e, por vezes, negada ou ofuscada. Logo, o presente trabalho tem por objetivo resgatar e esboçar - mesmo que com lacunas - parte desta historiografia dos intérpretes negros da diáspora no âmbito brasileiro. Visando essa empreitada, nos detemos mais especificamente no Brasil Colônia e Império (séculos XV a XIX) a fim de desnudar o mito do negro rústico e néscio que ainda assombra o conhecimento histórico de muitos pesquisadores. E com o intuito de explicitar os elos entre intérpretes negros no Brasil e na África fazemos um pequeno panorama deste ofício, de como ele era exercido em ambas as regiões geográficas, impulsionado pelos portugueses.

\section{A premissa africana}

Desde o Antigo Egito tem-se registro de uma figura que, a partir do século $\mathrm{XV}$, será denominada turgimão ${ }^{5}$. Este tipo de intérprete tinha como percurso o sequestro e a escravização com o intuito de se tornar mediador linguístico. Como a maioria desses intérpretes era oriunda de localidades

\footnotetext{
${ }^{5}$ Em uma acepção atual, segundo o Dicionário de Arabismos da Língua Portuguesa: “TURGIMÃo: s. m. de [ ت رجمان [turjman] "Intérprete" - tradutor oficial de uma missão diplomática em países do Oriente; (fig.) alcoviteiro; q.v. dragomano, drogomano, trejemane, turgimão, turchemão, turchimão e turcimão" (ALVES, 2013, p.839).
} 
que tinham por língua o árabe e o berbere na Antiguidade e logo depois o jalofo, o serere, o mandinga e o fula na época das navegações, o termo passou a ganhar a acepção de intérpretes falantes de línguas orientais. Contudo, a priori, o termo era usado para designar negros escravos que se tornaram intérpretes forçados em meio ao convívio com seus "conquistadores" (SILVA, 2011; PINHEIRO, 2005).

Fato importante a destacar é que mesmo nos potentados africanos ou sítios de poder (grosso modo, Estados) era comum a utilização de intérpretes no contato com estrangeiros. Segundo o pensamento dos grandes chefes africanos (séculos XVI-XVIII), adotar a escrita seria uma forma de submissão aos reinos europeus, logo, para se efetuar o contato com os europeus, eles se serviam da oralidade e da gestualidade como forma de comunicação, o que exigia mais ainda a categoria do intérprete, bem como de agentes especializados em tipos de comunicações e gêneros orais necessários para cada circunstância específica entre os africanos (LIENHARD, 2005). Um exemplo disso pode ser visto na seguinte imagem:

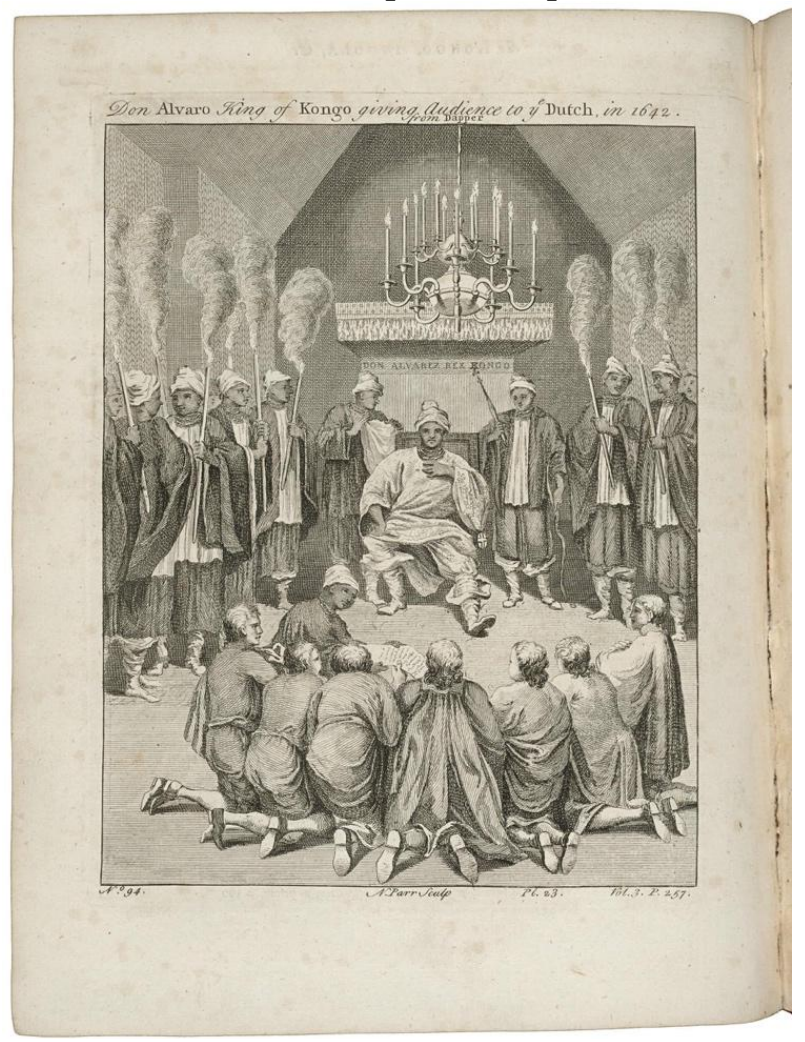


D. Alváro, rei do Congo em audiência com os holandeses em $1642^{6}$

[Desenho original do livro de Thomas Astley (ed). A nova Coleção Geral de viagens e excursões. Londres: 1745-1747, vol 3. p. 246]

Na figura acima, vê-se o negro que interpreta a mensagem oral e traduz o texto escrito dos holandeses que estão prostrados diante do rei do Congo. Esta fonte iconográfica não somente revela a importância do intérprete como também evidencia sua existência como parte integrante dos sítios de poder africanos. Convém mencionar que em cada potentado africano os intérpretes negros eram nomeados de diferentes maneiras que, de certa forma, revelavam seu status social, bem como sua função pública. A título de exemplo podemos mencionar os tendalas e os macunzes no potentado de Ngola (atual Angola) durante os séculos XVI a XVIII.

Segundo Flávia Maria de Carvalho (2010, 2013) o tendala (ou tandala) era um macota (isto é, qualquer membro da aristocracia local que tinha grande poder de decisão juntos aos sobas, esses últimos uma espécie de governador), geralmente escravo, que tinha como atribuição ser "administrador da Justiça, que deveria dar assistência aos sobas avassalados, e também assumia a função de intérprete, assistindo às embaixadas na resolução de assuntos referentes a tratados, guerras e queixas" (CARVALHO, 2010, p. 50). Interessante notar que o intérpreteescravo exercia seu papel em uma hierarquia social complexa em que homens de poder eram aconselhados por escravos7 ${ }^{7}$ O nome tendala também será adotado posteriormente pelos portugueses para denominar comandantes africanos em tropas portuguesas. O tendala-português era intérprete e guia nas guerras das missões de Portugal em terras africanas.

\footnotetext{
${ }^{6}$ Fonte da imagem do presente artigo:

$<$ https://upload.wikimedia.org/wikipedia/commons/1/15/AMH-7913-

KBDonAlvaro\%2CtheKingofCongo\%2CgivesanaudiencetotheDutchin1642.jpg >.

Acesso em 17 de julho 2017.

${ }^{7}$ De acordo com a historiadora Flávia Maria de Carvalho (2010, p. 50): “os tandalas faziam parte do grupo dos kijikus, nome dado à população escrava do reino do Ndongo. Eram escravizados de acordo com os métodos que predominavam antes da mercantilização dos escravos. Escravos eram pessoas que haviam contraído algum tipo de dívida e que por razões variadas não conseguiam quitá-las: filhos de escravos, ou prisioneiros de guerras, ou seja, bem diferente da noção de 'peças' que passou a prevalecer quando a escravidão se tornou um lucrativo negócio".
} 
Já o macunze, era uma espécie de mensageiro, emissário, embaixador ou delegado que levava consigo recados memorizados e depois os declamava na presença das autoridades competentes (ITO, 2016, p. 333). Seus recados tinham teor sigiloso, oficial, diplomático ou público e eram conhecidos como milongas (LIENHARD, 2005). Os macunzes eram os principais veículos de comunicação entre africanos e outros estrangeiros. Viajavam para resolver problemas com outros reinos representando as autoridades africanas (os sobas) e, geralmente, “eram os responsáveis pelas negociações que antecediam os contatos formais entre europeus e membros das elites políticas locais" (CARVALHO, 2010, p. 51). Em suma, o que se observa é que os macotas eram conselheiros especializados dos chefes africanos, sendo os tendalas conselheiros principais e os macunzes, embaixadores. Ambos eram intérpretes, um permanentemente (e escravo) ao lado do soba e o outro enviado (e nobre, possivelmente da família) do soba ao estrangeiro.

Outro exemplo de intérprete negro africano é o linguester ${ }^{8}$. Esta denominação surgiu no século XIX para identificar um tipo de contrabandista africano de escravos que atuava na África centro-ocidental. Era o intermediário bilíngue que monopolizava o comércio entre europeus e comerciantes do interior africano (ALMEIDA, 2012). E além disso,

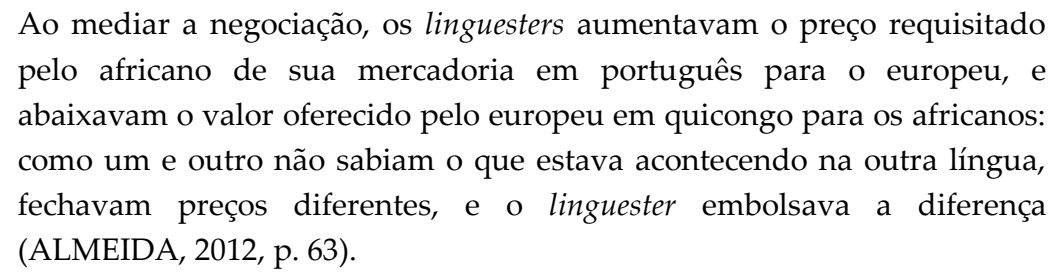

Isto é, o linguester surgiu na época em que a língua portuguesa era considerada uma língua franca para conquistas marítimas e tráfico de escravos. Este intérprete é qualificado como aquele que sabia falar a língua de branco (a língua portuguesa). De fato, o linguester obteve proficiência em língua portuguesa ao ser servo doméstico do branco. Ademais, com o

\footnotetext{
${ }^{8}$ Segundo o historiador Marcos Abreu Leitão de Almeida: “Como agente fundamental do comércio na região, a palavra em português para intérprete, o língua, foi incorporada tanto à língua inglesa como linguester, quanto ao fiote e outras variantes do quicongo como malinguice" (2012, p. 61).
} 
branco também aprendeu os usos e hábitos dos negócios, bem como a mandar em serviçais. Daí o porquê de ter havido africanos com este ofício, pois além da demanda comercial de escravos, havia igualmente um processo de transculturação dos litorais atlânticos da África em que certos elementos culturais iam sendo apropriados aos poucos pelos africanos devido aos habituais contatos com as culturas europeias na costa (ALMEIDA, 2012). Pode-se dizer que este é o primeiro intérprete negro à moda europeia porque sua existência e sua forma de atuação derivam das circunstâncias imperialistas impostas à África pelos colonizadores europeus.

Alguns dados importantes, dentre os quais nos deteremos em apenas dois, sobre os intérpretes africanos que falavam português, nos são desvendados pelas Cartas do Daomé, documento composto por 14 missivas, supostamente escritas pelos reis do Daomé aproximadamente entre 1790 e 1820, enviadas às autoridades portuguesas tanto no Brasil quanto em Portugal, reunidas em um único documento pelo antropólogo e historiador Luís Nicolau Parés e transcritas e publicadas na seção documentos da revista Afro-Ásia ${ }^{9}$ em 2013. A primeira informação que chama a atenção é justamente a relação entre tradução e interpretação e entre oralidade e escrita. Parés, ao analisar este fato, nos dá a seguinte informação:

[...] Os reis do Daomé não falavam nem escreviam em português, com exceção de algumas palavras. Suas intenções e decisões em política externa estavam, em parte, influenciadas por seus ministros e conselheiros. É provável que fossem estes, enquanto porta-vozes do rei, os responsáveis por ditar os enunciados que eram logo traduzidos pelos intérpretes ou línguas. Estes eram amiúde cativos portugueses (marinheiros ou outros) que o rei retinha na capital, Abomé, às vezes durante anos. Eles deviam ter uma compreensão precária do fongbe, uma língua tonal para a qual seus ouvidos não estavam treinados. Caso contrário, os tradutores podiam ser nativos com um domínio parcial do português, língua franca nas relações comerciais da região desde o século XV. Depois de traduzido, o enunciado oral devia ser transcrito, tarefa que cabia ao mesmo intérprete, caso soubesse escrever português, ou a um escrivão, que introduzia um novo nível de mediação.

\footnotetext{
${ }^{9}$ Site da revista: https://portalseer.ufba.br/index.php/afroasia/index
} 
Isto é, por mais que a tradição africana reconhecesse que a escrita era um tipo de dominação europeia, se admitia igualmente que ela era um instrumento muito eficaz de negociação e diplomacia. Cabia ao intérprete africano ou radicado na África, por vezes, traduzir da forma oral para a forma escrita, o que significava que traições, distorções, acréscimos ou mesmo cortes eram práticas comuns nesta modalidade de ato de interpretação-escrita. As Cartas do Daomé relatam que este processo era extremamente complexo. $\mathrm{O}$ intérprete escutava o rei, que ditava a missiva. Enquanto escutava o rei, traduzia a mensagem escrevendo-a no papel. Depois de terminada a mensagem ditada, a carta era lida/interpretada para conferência do conteúdo e, ao final, assinada pelo rei. Alguns intérpretes, ao escreverem/traduzirem a carta, faziam questão de afirmar que a carta tinha sido transcrita e continha as palavras tais quais ditas pelo rei - este é o caso do tenente negro Francisco Xavier Alvarez do Amaral.

Uma segunda informação importante revelada por essas cartas é que o língua/intérprete africano era denominado muitas vezes moço branco. Parés ratifica a informação em uma das notas feitas para a publicação das cartas afirmando o seguinte:

\footnotetext{
Os intérpretes, ou "moços brancos", capazes de escrever nas línguas europeias, eram figuras chave no comércio com os daomeanos. Eles não eram necessariamente "brancos", mas designados com essa categoria, yovo, pelo fato de saberem falar e escrever língua de branco. Ver carta 2, nota 18 . No reino de Uidá, havia chefes nativos associados a cada uma das nações europeias que ali comerciavam que dominavam as respectivas línguas. Também podiam ser utilizados prisioneiros portugueses como "línguas". Resultado das guerras nas praias de Porto Novo, desde pelo menos 1787, se prolongando até 1790, o rei Agonglo tinha vários desses prisioneiros: APEB, maço 193, “Francisco Antonio da Fonseca e Aragão ao governador da Bahia, Uidá, 20/12/1787; 04/01/1788, 16/08/1790" (PARÉS, 2013, p. 330, nota de rodapé 4) .
}

Desses moços brancos conhecidos, dois nomes são identificados nas cartas: o negro Luiz Caetano de Assumpção e o pardo Inocêncio Marques Santana. Ambos foram línguas que acompanharam os diversos embaixadores enviados pelos monarcas do Daomé. Cabe assinalar que esses dois intérpretes, provavelmente, são os únicos nomes conhecidos de 
línguas africanos que estiveram no Brasil. Possivelmente, muitos outros estiveram, mas não se sabem seus nomes ou estão no imaginário de africanos que estiveram no Brasil, como o caso do possível intérprete idoso de nome Dossyovo que teria sido enviado ao Brasil em busca da mãe do monarca Guezo (PARÉS, 2013).

\title{
Um ofício “inventado" pelos portugueses ${ }^{10}$
}

Os portugueses, junto aos espanhóis, foram considerados os grandes navegadores e "descobridores de terras" na época da expansão marítima europeia. Foram os portugueses em especial que desenvolveram grandes técnicas e instrumentos de navegação, construção de navios e "padrões normativos" para profissionais do mar. Dentre os investimentos da expansão imperialista estavam as técnicas de comunicação, importantes mecanismos para manter a engrenagem colonial. De acordo com o historiador Cláudio Costa Pinheiro,

\begin{abstract}
A conquista do périplo africano pressupôs, portanto, o domínio cartográfico de uma territorialidade, o conhecimento de populações costeiras e suas línguas. No fim do século $\mathrm{XV}$, os portugueses já haviam desenvolvido um interessante programa para o enfrentamento e tratamento sistemático das dificuldades de comunicação e, mais tarde, das próprias línguas que iam sendo contatadas. Muitas das viagens à África não tinham como objetivo (específico ou único) o estabelecimento de relações comerciais ou a obtenção de escravos como força de trabalho, mas sim a de intérpretes (em grande medida, também escravos) que viabilizassem, em um segundo momento, a continuidade do empreendimento expansionista-colonial (2005, p. 42-43).
\end{abstract}

Isto é, só era possível explorar as terras desconhecidas obtendo informações sobre elas e, para isso, era necessária a comunicação com os povos que lá viviam. Logo, uma das ferramentas para responder a essa dupla necessidade (informações e comunicação) era o intérprete. Convém mencionar que tal artifício exploratório era reforçado ainda mais graças às

\footnotetext{
${ }^{10}$ Uma visão minuciosa e mais ampla sobre o ofício de intérprete em Portugal (séc. XV a séc XIX) pode ser encontrada no trabalho de Garry Mullender (2015), intitulado The importance of interpreting during the Portuguese discoveries in Africa and Asia. Para o presente artigo, nos detemos apenas no ofício do intérprete negro no "sistema de intérpretes" colonial português.
} 
práticas civilizatórias e missionárias da fé cristã amplamente difundidas pelos invasores europeus. Todos esses ingredientes juntos viabilizavam, nos termos de Cláudio Pinheiro (2005), o paradigma: traduzir elé conquistar. Uma vez ambas as partes (europeus e africanos) se compreendendo bem, havia maior otimização das missões, do comércio e do tráfico de escravos.

Mas como se "produzia" um intérprete? Para mostrar este processo, vejamos o exemplo de Pedro de Cintra (? - 1484), navegador português que esteve a serviço da coroa portuguesa na costa ocidental da África, considerado descobridor da Guiné:

Item, para além deste Cabo do Monte, indo pela praia e para diante cerca de 60 milhas, encontra-se um outro pequeno cabo e não alto, que também apresenta em cima um montezinho; e a este cabo puseram o nome de Cabo Cortês. Aqui viram muitos fogos, na primeira noite, sobre as árvores e pela praia, feitos pelos negros, quando houveram vista dos primeiros navios de Cristãos, nunca dantes por eles vistos naquelas partes. E 16 milhas para além deste cabo, sempre ao longo daquela praia, há um grande bosque, com muitas árvores que vão até ao mar; e em frente deste bosque lançou âncora a caravela. À qual caravela vieram umas almadias (ou «zopoli» pequenos), em cada uma das quais vinham 2 ou 3 homens, todos nus; os quais traziam nas mãos uns paus aguçados na ponta, parecidos com os seus dardos; e alguns deles tinham uns cutelos pequenos, e, todos eles, duas adargas de couro com 3 arcos. E vieram à caravela. Tinham as orelhas todas furadas em volta, e o nariz, também, por baixo; e tinham, alguns deles, ao pescoço, umas résteas de dentes que pareciam de homem. Falaram-lhes diversos turgimãos negros que estavam naquelas caravelas, mas nunca lhes entenderam uma só palavra. E, embora não se pudesse entender coisa alguma daqueles negros dos «zopoli», 3 deles entraram para as caravelas. E, destes 3 os Portugueses tomaram um, e aos outros deixaram ir. E isto, para cumprir com a ordem do seu senhor rei, o qual lhes ordenou que, da terra distante aonde chegassem, não querendo ir mais para diante, se porventura não fossem entendidos os habitantes, procurassem trazer-lhe um dos negros do país, a bem ou a mal, a fim de por ele saber, com o tempo ou por via dos muitos outros turgimãos negros que se acham em Portugal ou depois que ele aprendesse a falar, algumas novas daqueles seus países de Negros. Por esta razão, retiveram este negro; o qual, em suma, conduziram a Portugal. A este negro o sobredito senhor Rei de Portugal pô-lo a falar com vários negros; e, finalmente, de uma sua mulher negra, escrava de um cidadão de Lisboa, e que também era de terras distantes, foi entendido, não pela 
sua própria linguagem, mas por uma outra linguagem que ele e ela conheciam (CADAMOSTO, p. 177-178, 1948) ${ }^{11}$.

A partir deste relato, que não é diferente de muitos outros da época, percebe-se que os nativos eram levados à força para Portugal (a mando real), habituados aos costumes (e à religião) e submetidos à aprendizagem da língua portuguesa, com especial atenção para que o negro servisse posteriormente como intérprete na conquista da terra longínqua até então desconhecida pela Coroa. Fatos interessantes na história de Pedro de Cintra são que não somente homens, mas também mulheres negras serviam de intérpretes (mesmo em menor grau) e que entre os negros igualmente havia língua(s) franca(s) - portanto, eram já na África bi/pluri/multilíngues ${ }^{12} \mathrm{e}$ propensos à aprendizagem de línguas. Além dos cativos, o degredado (criminoso punido com o degredo) e o lançado (colonizador português fixado na África) também tinham por desígnio serem intérpretes. Todos aprendiam a língua pelo método da imersão linguística e eram assistidos pela Coroa portuguesa que muito os valorizava, por vezes com títulos de nobreza.

O historiador Cláudio Pinheiro (2005) reforça a importância dos intérpretes para a Coroa portuguesa ao mencionar que Portugal criou um verdadeiro "sistema de intérpretes" que foi largamente difundido entre os outros países europeus nas conquistas coloniais. Pinheiro (2005) destaca que em Portugal havia as escolas de tradutores, responsáveis pela formação destes intérpretes. Era uma preocupação portuguesa formar intérpretes tanto em línguas orientais ${ }^{13}$ quanto em línguas da América do Sul. Há relatos em especial sobre negros do Congo que eram trazidos para Portugal “como 'estudantes', sendo sustentados pela Coroa em sua estada e nos meios necessários à educação, que incluía mais do que o aprendizado da língua portuguesa" (PINHEIRO, 2005, p. 45). Estes eram chamados de

\footnotetext{
${ }^{11}$ Nesta citação, manteve-se a ortografia e a sintaxe da época.

${ }^{12}$ Marcos Abreu Leitão de Almeida (2014) menciona que entre os africanos já era comum o bilinguismo passivo, o multilinguísmo generalizado e a utilização de línguas francas pela proximidade das línguas e/ou de famílias de línguas.

13 Sobre este assunto consultar: Dejanirah Couto (2011) e Maria Manuela Gomes Paiva (2011). Convém saber que o intérprete oriental a serviço da Coroa portuguesa era denominado jurubaça.
} 
"bolseiros" (ou filhados ${ }^{14}$ ) e, além de aprenderem a língua, vinham aprender também "os preceitos da lei" tanto portuguesa quanto cristã. Somado a isso,

\begin{abstract}
Ocorre, entretanto, que estas escolas de tradutores não se destinavam apenas à capacitação propriamente de intérpretes, mas também à formação de elites coloniais nativas associadas à coroa portuguesa por laços de vassalagem, e ainda a habilitar quadros que integrassem, de alguma maneira, o aparelho colonial administrativo do ultramar. As circunstâncias que envolvem a presença portuguesa no Congo, ao longo dos séculos XV e XVI, são bastante expressivas neste sentido. Além da já mencionada existência de nativos desta localidade como bolseiros em colégios religiosos de Lisboa, foi entre os reinados de D. João II e D. Manuel (1495-1521) quando talvez mais intensamente se investiu neste sentido. Por determinação régia sua, os "bolseiros" deviam ser "fidalgos, e dos honrados", reservando-lhes inclusive o título de "Dom" (PINHEIRO, 2005, p. 46).
\end{abstract}

Esse "sistema de intérpretes" estruturado pelos portugueses se revelou extremamente complexo, pois, se, de um lado, auxiliava na ascensão social de negros, cativos de outras nacionalidades ou radicados portugueses das colônias; do outro lado, era exercido, majoritariamente, por uma parcela da sociedade portuguesa marginalizada. Para a pesquisadora Dejanirah Couto (2011), muitos fatores contribuíam ainda mais para o difícil papel de ser intérprete : 1 ) ofício associado às missões de espionagens e negociações secretas; 2) cargo que exigia segredo de Estado e ao mesmo tempo acobertamento das mazelas do poder; 3) imagem de "alma corrompida" atribuída ao intérprete porque havia a crença de que se utilizar de outras línguas implicava o emprego de mecanismos mentais de outros mundos; 4) posição de inferioridade dos poderosos diante dos sabedores de línguas escritas e orais, tornando-os dependentes deles para

\footnotetext{
${ }^{14}$ Segundo Bethania Mariani (2007, p.89), “o língua (ou turgimão) designa um lugar de intérprete e uma função: atuar como intermediário em transações comerciais variadas. A atuação dos línguas, portanto, existe antes da chegada do processo colonizador propriamente dito, ou seja, antes de a Coroa Portuguesa sedimentar administrativamente e religiosamente a terra descoberta, os intérpretes eram deixados na costa para aprender a língua desconhecida, os costumes do lugar, a geografia e a localização das riquezas. Seguindo um caminho inverso, relatos atestam que na costa da África, durante o século XV, negros eram 'filhados', aprisionados, e levados para Portugal para aprenderem a língua e os costumes portugueses".
} 
efetivar a conquista, e 5) má retribuição econômica, motivo que levava alguns intérpretes do sistema português a também auxiliarem outros reinos imperialistas ou mesmo a se separarem da Coroa trabalhando de "forma autônoma". Em suma, todos esses dados faziam dos intérpretes seres extremamente suspeitos, vigiados e vulneráveis.

Dentro deste sistema de intérpretes, o número de designações para os diferentes tipos de mediadores linguísticos é considerável. Por isso, neste trabalho consideramos apenas os mais conhecidos e mencionados nos estudos aos quais até aqui tivemos acesso:

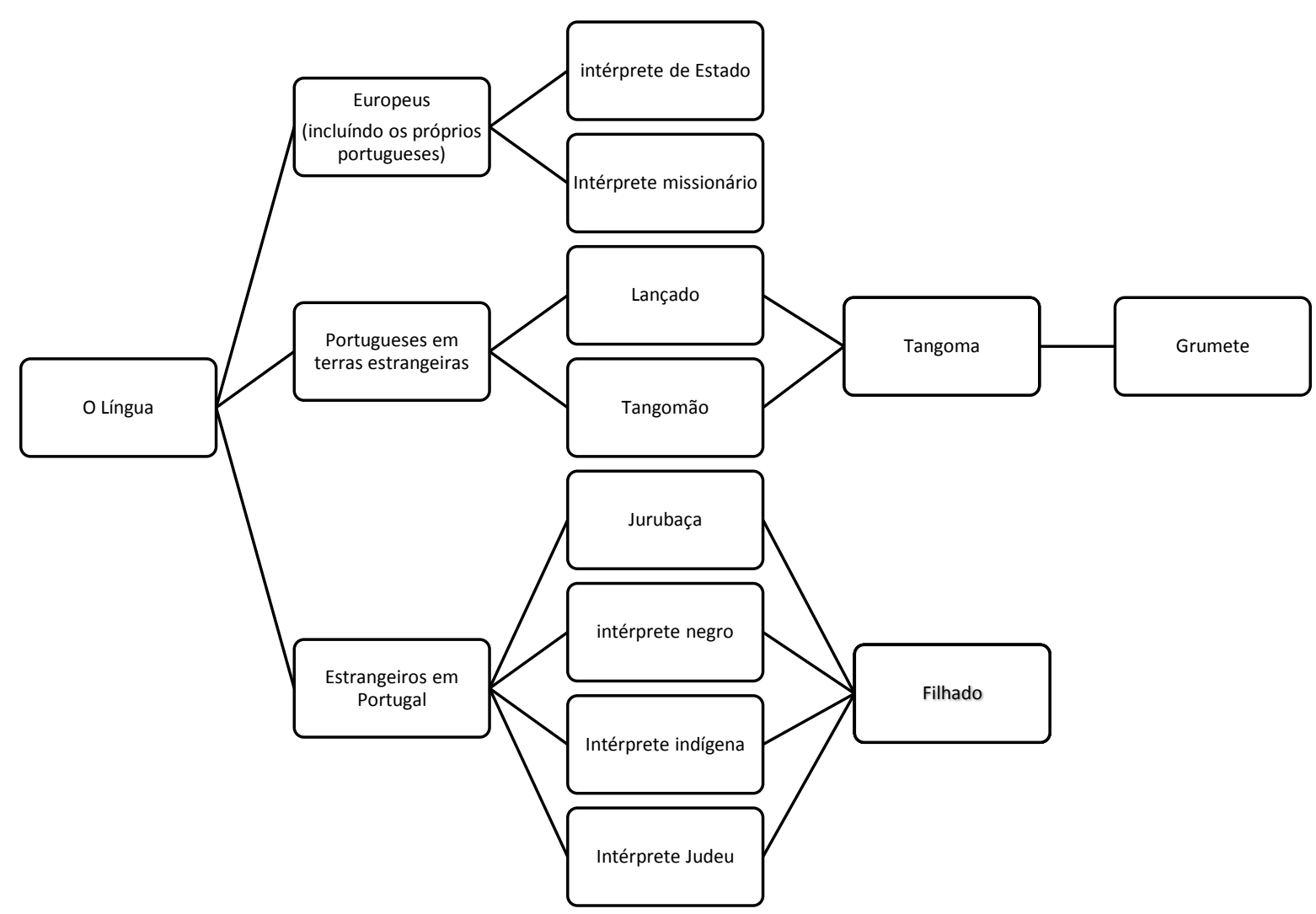

Tipos de intérpretes do Império Português (s. XV a XIX)

Fonte: diagrama elaborado pelo autor 
Como é possível perceber no diagrama acima, o termo língua, no masculino ("o língua") era a designação mais geral da época para nomear o ofício de intérprete. No sistema de intérpretes português existiam três grandes grupos: os próprios portugueses ou outros europeus a serviço da Coroa, os portugueses que se lançavam (por vontade própria ou imposição) em terras estrangeiras, e os estrangeiros (a maioria escravos) trazidos para se aperfeiçoarem como mediadores linguísticos em Portugal. Os intérpretes negros ou tiveram contato com estes três grupos ou estavam inseridos no meio deles.

Na missionação feita na África (e também em todas as colônias portuguesas), os missionários das mais diversas ordens religiosas eram acompanhados por intérpretes nativos (os filhados) até adquirirem proficiência na língua - aprendiam pelo método da imersão linguística "assistida". Entretanto, é oportuno mencionar que o convívio com o intérprete negro fazia com que o missionário produzisse outros tipos de tecnologias linguísticas a favor da colonização portuguesa: dicionários, glossários, vocabulários, guias de comunicação e gramáticas. Acontecia uma espécie de tradução colaborativa em que a parte escrita concerne ao missionário e a "parte oral" ao intérprete nativo cristianizado, ou seja, muitas vezes o intérprete atuava como informante, interlocutor e revisor na composição de livros de referência linguística da língua nativa para a língua portuguesa (PINHEIRO, 2005). Graças a essa interlocução, era possível também elaborar materiais didáticos para o ensino de português aos nativos (as cartinhas ${ }^{15}$ ) e o ensino de línguas estrangeiras africanas para os portugueses.

No que tange aos portugueses em terras africanas, basicamente existiram dois tipos de intérpretes: os lançados ${ }^{16}$ e os tangomãos ${ }^{17}$. Ambos, chefes de tráfico negreiro, eram portugueses literalmente lançados (à força ou por vontade própria) na costa africana. O primeiro se mantinha no

\footnotetext{
15 "Cartilhas de aprendizado básico da língua, nesse caso, dirigidas a não-falantes de português" (PINHEIRO, 2005, p. 55).

${ }^{16}$ Para um maior aprofundamento: SILVA, 2011, em particular, capítulo 7 "Os lançados”, e SOARES, 2000.

${ }^{17}$ Para saber mais, ler PINHEIRO, 2011 e ZERON, 1999.
} 
continente africano sendo fiel à Coroa portuguesa, e o segundo era o desbravador de terras africanas adentro e, muitas vezes, com maior vínculo com um chefe africano. No entanto, o que é mais significativo para esta pesquisa são os dois tipos de intérpretes negros que muito contribuíram para o sucesso de lançados e tangomãos: a tangoma e o grumete.

A tangoma, grosso modo africana casada com português, era uma intermediária cultural, linguística e biológica, nos termos de Alida Metcalf (2005). Alberto da Costa e Silva nos dá detalhes desta figura:

\begin{abstract}
Graças às novas esposas, os portugueses familiarizaram-se com os costumes da terra e passaram a viver sem ofendê-los. Tornaram-se fluentes na língua local e capazes também de entender os falares dos povos vizinhos, ou porque pronto se fizeram polígamos, ou porque sua companheira, nos raros casos em que era a única, dominava mais de um idioma (como sucede em geral com os africanos). Com as mulheres, os portugueses aprenderam as regras locais de compra, distribuição, venda e regateio. Descobriram como competir com os mercadores mandingas, ou aliar-se a eles, na recepção dos produtos que interessavam às caravelas e às naus. $\mathrm{E}$ as mulheres pronto se convenceram de que também muito tinham o que aprender com os maridos brancos (e, mais tarde, mulatos), no negociar com os europeus. Foram-se, no andar do tempo, aportuguesando, enquanto os maridos se africanizavam.
\end{abstract}

[...] As tangomas, como eram chamadas, ou tungumas, passaram a frequentar mercados mais distantes e a movimentar-se mais rapidamente entre eles, não mais apenas como vendedoras de alimentos, mas para colocar e arrecadar alguns dos produtos que comerciavam os seus maridos, como a cola, a cera, o almíscar, os panos, e o algodão com que os teciam, e o índigo com que os tingiam. As mulheres tinham, aliás, uma vantagem de grande peso sobre os homens: até mesmo durante conflitos armados, não lhes era negado, nem às crianças, o acesso aos mercados dos adversários. Com isso impedia-se a interrupção do abastecimento normal de víveres às comunidades em luta. Mas essa prerrogativa podia ser usada às avessas pelas mulheres, para castigar uma cidade, um vilarejo ou um conjunto de aldeias. Ao se afastarem voluntariamente das feiras de uma povoação sitiada, negavam-lhe parte dos alimentos que esta se acostumara a receber e contribuíam para sua rendição. (SILVA, 2011, p.168; p. 178-179) 
Essas mulheres intermediárias ${ }^{18}$ eram as responsáveis por um maior acomodamento dos portugueses em terras africanas. Como intermediárias linguísticas, facilitavam a aprendizagem do lançado ou tangomão da língua local; como intermediárias culturais, mediavam os costumes e hábitos de seu povo a fim de que seu marido português os assimilasse da melhor forma e o mais rápido possível; e como intermediárias biológicas procriavam e davam educação bicultural aos filhos para legar à família a posição de prestígio alcançada pelo marido. Alberto da Costa e Silva (2011), em seu livro A manilha e o libambo, menciona vários exemplos de tangomas que ficaram conhecidas na África setecentista e afirma que o casamento entre mulheres africanas e portugueses também era uma política colonial no que tange à língua, aos costumes e ao povoamento dos territórios conquistados.

O grumete ${ }^{19}$, nas palavras de Alberto da Costa e Silva (2011, p. 178),

[...] passou a aplicar-se aos homens e às mulheres que serviam aos lançados e moravam ao lado deles, e vestiam-se à europeia, e construíam casas com o reboco pintado de branco, e falavam o português ou, mais geralmente, os crioulos que se iam desenvolvendo ao longo da Costa e nas ilhas de Cabo Verde. Os grumetes começaram como remeiros, carregadores, guias e criados, mas pronto se fizeram compradores e vendedores em nome dos patrões, e intérpretes, e mensageiros, e pilotos, e construtores de barcos.

Isto é, os grumetes, dentro da hierarquia de intérpretes portugueses, eram uma outra categoria de mediador linguístico abaixo dos lançados e tangomãos exercida exclusivamente por negros que assimilavam a cultura portuguesa difundida por seu superior - no caso, um lançado ou tangomão. Eles obedeciam igualmente às tangomas, "usavam quase sempre o sobrenome do lançado que os protegia e era por eles protegido" (SILVA, 2011, p. 178), bem como se consideravam cristãos e portugueses.

\footnotetext{
18 O termo "intermediária", que tomamos emprestado de Alida Metcalf (2008), é a tradução mais próxima para o termo de língua inglesa go-betweens para se referir às mulheres intermediárias no Brasil colonial. Segundo a autora, as mulheres foram muito mais que intérpretes linguísticas e culturais. Tiveram função física, biológica, transacional e representacional.

19 No Brasil, essa palavra se consolidou apenas como aprendiz de marinheiro, ou a mais baixa escala da hierarquia da Marinha exercida inicialmente só por negros.
} 
Muitos grumetes eram oriundos da descendência da esposa do lançado ou tangomão, mas, apesar disso, tratados, essencialmente, como escravos.

Na ausência de um lançado ou tangomão, quem ocupava seu lugar era a tangoma ou o grumete mais velho (ou de mais prestígio). Esses dois intermediários significavam a continuidade da política colonial exercida pelos portugueses deixados na costa africana e igualmente representavam o sucesso do sistema de intérpretes inaugurado e aperfeiçoado pela Coroa portuguesa durante muitos anos. Visibilizar estas duas figuras na história da interpretação é de alguma forma mostrar a parte ainda obscura deste "sistema de intérpretes" tão moderno para a época e lembrado com êxito apenas por seus intérpretes europeus, como se outros povos não tivessem dado sua contribuição para seu modus operandi.

Um dos pontos centrais e, talvez, o mais importante para o sistema de intérpretes de Portugal era a motivação oferecida a todos os escravos que almejassem o cargo de mediador linguístico-cultural. Luís de Cadamosto, navegador veneziano que esteve a serviço da Coroa portuguesa na África no século XV, explica o que era tal oferta:

[...] E, navegando, chegámos à boca de um rio, o qual mostrava não ser inferior ao sobredito rio de Senega; pelo que, vendo nós tão belo rio, e parecendo a terra linda e abundante de árvores até à praia, lançámos ferro, e deliberámos mandar a terra um dos nossos turgimãos, porque todos os nossos navios tinham turgimãos negros, trazidos de Portugal, os quais turgimãos são escravos negros vendidos por aquele senhor de Senega aos primeiros cristãos portugueses que vieram descobrir o país dos Negros; os quais escravos se fizeram cristãos em Portugal, e aprenderam bem a língua hispânica; e tínhamo-los havido dos seus donos, com a retribuição e pagamento de lhes dar um escravo por cada um, a escolher em todo o nosso monte, pelo seu trabalho de turgimania: e, em dando cada um destes turgimãos ao seu dono 4 escravos, eles os deixam forros. Por este meio, muitos escravos ficam forros, depois, por este meio da turgimania. (CADAMOSTO ${ }^{20}$, p. 148-149, 1948).

Como se observa no relato do navegante italiano, o estímulo para ser intérprete no "sistema de intérpretes português" é a conquista da

\footnotetext{
${ }^{20}$ Agradeço a Roch Duval por me auxiliar a obter uma cópia desta memória de Cadamosto em edição portuguesa.
} 
liberdade. Para obter este bem, os negros se comprometiam a escravizar outros negros, mas também arriscavam suas vidas, já que deviam ser mediadores linguístico-culturais por imposição de seus senhores com os mais diferentes povos, não sabendo o que lhes poderia acontecer nestes momentos de contato com grupos sociais, por vezes desconhecidos ou nãoreceptivos. A turgimania - ou o exercício do ofício de intérprete nessas condições -, além de oferecer a alforria, era almejada pelos negros para escapar de maus-tratos graves, para diferenciação social e hierárquica dentre os outros negros e valorização do negro entre os brancos. Todos esses fatores contribuíam para que o negro desempenhasse melhor ainda sua função de intérprete ao acompanhar os navegadores enviados pela Coroa portuguesa.

\section{O intérprete negro no Brasil}

Os primeiros intérpretes negros de que se tem notícia no Brasil são os mediadores linguísticos africanos que vinham nos tumbeiros, as embarcações que realizavam o tráfico de escravizados da África ao Brasil (RODRIGUES, 1994, 2000). Podemos atestar tal fato por meio de uma das consultas do Conselho Ultramarino, um dos documentos que fazem parte da Legislação sobre escravos africanos na América portuguesa (2000), organizado pela historiadora Silvia Hunold Lara:

\section{Consulta 20 de novembro de 1694}

Senhor. Por carta de 2 de abril de 1693 foi vossa majestade servido ordenar ao Cabido da Sé de Angola que nas embarcações que daquela cidade partirem para o Brasil tenha o particular cuidado em que nelas vão sacerdotes práticos nas línguas dos sertões, para que assim melhor se acuda à salvação dos escravos que nelas se embarcaram, e quando os não houvesse se procurasse tal forma no modo de embarcar os negros que fosse a carregação em cada embarcação, daqueles que os capelão soubesse a língua.

A esta carta responde o dito Cabido por outra de 28 de maio deste ano, que esta ordem de vossa majestade se não pode de nenhuma maneira observar, porque do dilatado sertão daquele Reino vem de cada parte dele pouca quantidade de escravos, com que se faz a carga de cada navio, porquanto se se estivera esperando viessem só de uma terra, seria impossível sair cada ano um patacho, o que era em grande prejuízo do 
comércio, e dos vassalos de vossa majestade e esta mesma verdade imaginara o dito Cabido significara a vossa majestade o governador daquele Reino, que o maior remédio que a esta recomendação se podia dar, era mandar por capelães os filhos daquele Reino, como assim observa os quais são em maior parte das línguas daquele sertão peritos, e quando em alguma não estejam correntes, sempre na tal embarcação vinham alguns escravos ladinos que serviam de intérpretes, de que muitas vezes se valiam, e o mesmo fazem os missionários capuchos por aquele sertão; e que por conta do Cabido ficava o replicar não haver falta dos ditos capelães para que não experimentassem aquelas almas nenhum desamparo, e sossegasse juntamente o ardentíssimo zelo, com que vossa majestade procura todo o bem e salvação de seus vassalos. [...] (LARA, 2000, p. 453-454).

Como se percebe na consulta, havia a preocupação de que houvesse dentro das embarcações intérpretes dos negros africanos a fim de "auxiliálos" em suas necessidades - isto é, com o objetivo de poderem suportar a viagem até a chegada ao Brasil. Por vezes, esses intérpretes ou eram missionários que já haviam aprendido línguas africanas ou africanos que sabiam a língua portuguesa, os ladinos.

É sabido que a captura, venda e tráfico de escravos tinham dois princípios básicos: a escravização de cativos de diferentes povos e a preferência por mulheres e crianças (SILVA, 2011). Tais princípios eram uma forma de evitar que os negros se unissem e se rebelassem em novas terras, bem como aprendessem mais rápido o português (ou o pidgin português) e se ajudassem na aculturação. Contrariamente ao que se pensa, o tráfico de negros era, majoritariamente, de mulheres e crianças porque essas duas categorias eram menos perigosas, no tocante a promover uma rebelião, assim como a mulher se submetia mais ao regime de escravidão com receio de fazerem mal aos seus filhos; além disso, as crianças cresciam na cultura escravocrata já sabendo seu lugar na pirâmide social colonial (SILVA, 2011). Todavia, os registros documentais dessas mulheres e crianças são pouco conhecidos ou estão dispersos em lugares ainda não identificados, o que nos leva a relatar, em maior parte, os casos de negros do sexo masculino na maioria das situações de interpretação no Brasil. É claro que esse é um problema historiográfico da história do Brasil, que vem 
sendo revisto (ou corrigido) em várias áreas, em particular no domínio da História das Mulheres.

Convém mencionar que algumas mulheres negras, muito conhecidas como líderes de quilombos e rebeliões (TELES, 1999), provavelmente foram intérpretes: no século XVII, Aqualtune e Dandara; no século XVIII, Felipa Maria Aranha, Maria Luiza Piriá, Maria Juvita e Teresa de Quariterê (conhecida também pelo nome Teresa de Benguela); e no século XIX, Zeferina, Maria Filipa de Oliveira, Zacimba Gaba e Mariana Crioula (SCHUMAHER, BRAZIL, 2006). Apesar de não haver relatos historiográficos, até o presente momento, sobre em que língua e como se comunicavam essas mulheres com os negros e índios dos quilombos e rebeliões, o fato é que, mesmo todas tendo língua materna por vezes diferente da de outros integrantes da comunidade da qual faziam parte, e mesmo havendo línguas francas utilizadas por elas na comunicação nos quilombos e rebeliões, todas compreendiam e falavam a língua portuguesa - língua de negociação, comunicação e interação com os brancos.

Dentro dos navios em direção ao Brasil, eram transportados negros de diversas etnias e regiões geográficas da África, e um ou mais intérpretes negros que falavam várias línguas (inclusive português) ou mesmo línguas francas eram os responsáveis por intermediar o contato entre os escravos e os capitães dos navios (ALMEIDA, 2014; RODRIGUES, 1994, 2000), hábito recorrente em todo o Brasil Colônia e Império. O ex-escravo Mahommah Gardo Baquaqua [1824?-1857?] (2017, p.54) relata, após ter chegado a Pernambuco, sobre o intérprete negro do tumbeiro: “Alguns dos escravos a bordo sabiam falar português. Tinham vivido no litoral com famílias portuguesas, então tornaram-se nossos intérpretes. Não foram colocados no porão como o resto de nós, mas desciam de vez em quando para nos dizer uma coisa ou outra". De fato, o número de escravos vindos do continente africano é imenso, as etnias distribuídas no Brasil ainda estão sendo identificadas por pesquisadores das mais diversas áreas. Para se ter ideia de onde vinham os escravos, a quantidade e como eram denominados, a especialista em línguas africanas Yeda Pessoa de Castro (2005) aponta os seguintes dados: 
DISTRIBUIÇÃO E CONCENTRAÇÃO GEOGRÁFICA DE NEGROS NO BRASIL (CASTRO, 2005, p. 45)

\begin{tabular}{|c|c|c|c|}
\hline \multirow{2}{*}{$\begin{array}{c}\text { Ciclos \& Números de } \\
\text { negros }\end{array}$} & \multicolumn{2}{|c|}{ Acontecimentos } & \multirow{2}{*}{$\begin{array}{l}\text { Denominações } \\
\text { dos negros }\end{array}$} \\
\hline & Internos & Externos & \\
\hline $\begin{array}{c}\text { Séc. XVI } \\
\text { Guiné } \\
\text { (toda costa atlântica) } \\
\pm \\
30.000\end{array}$ & $\begin{array}{l}\text { Posse e desbravamento } \\
\text { da terra. Introdução da } \\
\text { cana de açúcar, do gado e } \\
\text { engenhos. Escravidão } \\
\text { indígena. Fundação da } \\
\text { cidade do Salvador, } \\
\text { primeira capital da } \\
\text { América Portuguesa. }\end{array}$ & $\begin{array}{l}\text { 1482, construído o forte da } \\
\text { Mina, na costa de Gana. } \\
\text { Tráfico já existente para } \\
\text { Portugal, desde o séc. XV. } \\
\text { Desastrosa tentativa de } \\
\text { evangelização no Reino do } \\
\text { Congo. }\end{array}$ & $\begin{array}{l}\text { Negro da Guiné } \\
\text { Negro da Costa } \\
\text { Negro do Congo } \\
\text { Gentio da Guiné } \\
\text { Gentio da Costa }\end{array}$ \\
\hline $\begin{array}{c}\text { Séc. XVII } \\
\text { Congo-Angola } \\
\pm \\
800.000\end{array}$ & 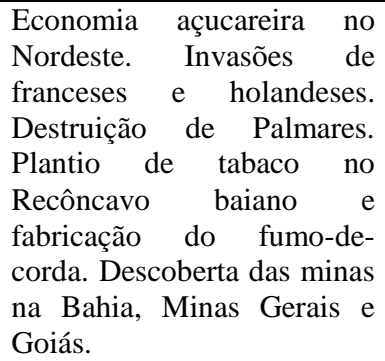 & $\begin{array}{l}\text { Comércio de escravos feito } \\
\text { através de pombeiros. } \\
\text { Decadência do Congo e } \\
\text { concentração do tráfico em } \\
\text { Luanda, depois Benguela. } \\
\text { Enviada da Bahia esquadra } \\
\text { para desocupação de Luanda } \\
\text { pelos holandeses, em } 1637 . \\
\text { Início do tráfico no Golfo de } \\
\text { Benim. }\end{array}$ & $\begin{array}{l}\text { Congos } \\
\text { Angolas } \\
\text { Cabindas } \\
\text { Benguelas } \\
\text { Mandingas } \\
\text { Minas }\end{array}$ \\
\hline $\begin{array}{c}\text { Séc. XVIII } \\
\text { Costa da Mina } \\
\text { (ao longo da costa de } \\
\text { Gana, Togo, Benim). } \\
\pm \\
2.500 .000\end{array}$ & $\begin{array}{l}\text { Companhia do Grão-Pará e } \\
\text { Maranhão e o comércio do } \\
\text { algodão. Aumento na } \\
\text { produção e exportação do } \\
\text { fumo-de-corda da Bahia } \\
\text { para o Daomé. A corrida } \\
\text { para as minas. Introdução } \\
\text { maciça de jejes e minas. } \\
\text { Transferência da capital para } \\
\text { o Rio de Janeiro. Importação } \\
\text { de mulheres. Tráfico com } \\
\text { Moçambique. }\end{array}$ & $\begin{array}{l}\text { Dependência comercial com } \\
\text { o forte da Mina. } \\
\text { Concorrência com França, } \\
\text { Holanda, Espanha e } \\
\text { Inglaterra. Em 1721, é } \\
\text { construído o forte de Uidá } \\
\text { com aumento do tráfico no } \\
\text { Golfo de Benim. Comércio } \\
\text { de fumo e de escravos feito } \\
\text { com os régulos locais por } \\
\text { crioulos da Bahia, ali } \\
\text { estabelecidos. }\end{array}$ & $\begin{array}{c}\text { Angolas } \\
\text { Congos } \\
\text { Cabindas } \\
\text { Benguelas } \\
\text { Jejes } \\
\text { Minas } \\
\text { Ardras } \\
\text { Savalus } \\
\text { Nagôs } \\
\text { Moçambiques } \\
\text { Quelimanes }\end{array}$ \\
\hline $\begin{array}{c}\text { Séc. XIX } \\
\text { Baía de Benim, Angola } \\
\mathrm{e} \\
\text { Contra-Costa. Tráfico } \\
\text { interno } \\
\pm \\
1.500 .000 \\
\text { (até } 1830)\end{array}$ & $\begin{array}{l}\text { Família Real no Rio de } \\
\text { Janeiro, feita } \\
\text { Abertura dos apital. } \\
\text { desenvolvimento urbano e } \\
\text { introdução maciça de oeste- } \\
\text { africanos nas cidades. } \\
\text { Revolta de negros } \\
\text { islamizados ou malês na } \\
\text { Bahia. Fim do tráfico } \\
\text { transatlântico, cerca de } \\
\text { 1853. Tráfico interno até a } \\
\text { abolição da escravatura em } \\
\text { 1888. Comércio de } \\
\text { produtos-da-costa e retorno } \\
\text { de africanos libertos e } \\
\text { descendentes para a África } \\
\text { Ocidental, via Lagos. }\end{array}$ & $\begin{array}{l}\text { Avanço do islamismo com } \\
\text { guerras interétnicas na } \\
\text { Nigéria. Destruição de Oió, } \\
\text { em 1830. Lagos como centro } \\
\text { do protetorado inglês e do } \\
\text { comércio de produtos-da- } \\
\text { costa com a Bahia. Os agudás } \\
\text { e as comunidades brasileiras } \\
\text { fundadas na Nigéria, Benim e } \\
\text { Togo, pelos retornados. } \\
\text { Suspensa, em 1903, a linha } \\
\text { de barcos "Brazils-Lagos". }\end{array}$ & $\begin{array}{l}\text { Angolas Congos } \\
\text { Jejes } \\
\text { Mahis } \\
\text { Nagôs } \\
\text { Hauçás Grunces } \\
\text { Canures } \\
\text { Tapas } \\
\text { Bornus }\end{array}$ \\
\hline
\end{tabular}


Como se vê no esboço histórico de Yeda de Castro, o número de grupos africanos na história do Brasil é grande e, por vezes, são classificados segundo o ciclo econômico brasileiro. Por exemplo, segundo a pesquisadora (CASTRO, 2014), o número de mulheres vindas para o Brasil no século XVIII para as regiões mineradoras está ligado diretamente ao fato de que havia o mito de que um bom minerador necessitava de uma "escrava mina". O negro oriundo da Costa da Mina - região aurífera africana à época - era tido como mais inteligente e laborioso, logo, mais apto para este serviço, e as mulheres de lá eram "nadegudas e alcatreiras", possuíam elogiados atributos físicos e suposta exuberância sexual - o que fez Minas Gerais à época ficar conhecida pelos grandes prostíbulos e concubinas negras. É claro que entre essas mulheres inteligentes e laboriosas possivelmente havia aquelas que eram intérpretes, mas ainda se desconhecem, em maior parte, seus nomes e situações específicas. Provavelmente, dos casos conhecidos de intérpretes negras, o de Vitória mereça mais destaque. A intérprete Vitória ficou conhecida por ser a intermediária em um tratado de paz entre os portugueses e os indígenas guaicurus em Mato Grosso em 1791 (CARVALHO, 2012, p. 207). Vitória, junto com um grupo de escravizados, visava fugir quando foram abordados pelos índios. A intérprete negra foi a única do grupo mantida com vida entre os guaicurus e feita cativa e intérprete dos índios nas negociações com os portugueses. Possivelmente tenha ficado um bom tempo com os índios e aprendido a língua por imersão antes destas negociações.

Saliente-se que o intérprete negro no Brasil se enquadrava no grupo conhecido como negros ladinos, ou seja, que tinham proficiência em língua portuguesa, em contraposição aos crioulos, que já eram negros nascidos no Brasil e, portanto, tinham a língua portuguesa como língua materna; e aos boçais, que eram inaptos para se comunicar em português (LIMA, 2014). Desta maneira, vemos que os atos de interpretação na vida dos escravos no Brasil eram algo corriqueiro, visto que havia mais negros estrangeiros do que nascidos na terra. Além disso, parece-nos que como profissão oficial pouquíssimos negros no Brasil exerceram a carreira de intérprete, o que, de 
um lado, torna este ofício invisível do ponto de vista histórico-socioétnico e, de outro, decorre que tal ofício era algo concernente a negros ladinos e exercido conforme a necessidade do contexto informal (e, frequentemente, não-oficial) em que o negro estava ou era obrigado a estar.

Um relato interessante sobre negros ladinos no século XVII é o acordo de paz assinado entre Gangazumba e Pedro de Almeida a fim de, um lado, assegurar a estabilidade do governo em Pernambuco e, do outro, fortalecer a linhagem e evitar a escravização dos negros de Palmares. Para garantir tal empreitada os soldados do Terço ${ }^{21}$ de Henrique Dias (ou Terço de Gente Preta) - Os Henriques -, que eram negros, auxiliaram nessa negociação como intérpretes (LARA, 2008). Eram os henriques que levavam as cartas do governador de Pernambuco e tinham a capacidade de explicá-las e traduzi-las oralmente no quilombo de Palmares. Destaca-se que esses soldados-intérpretes negros eram "pagos" (recebiam algum beneficio) e "livres" (liberdade condicionada e limitada) quando decidiam fazer parte do Terço de Henrique. De fato, entre os séculos XVII e XVIII, alguns membros da população negra masculina, para obter algum tipo de hierarquização ou distinção/ascensão social, participavam da esfera militar colonial (MATTOS, 2007). Se, de uma parte, os Henriques eram considerados "soldados oficiais da coroa", de outra parte, eram vistos como ex-escravos protegidos e úteis ou negros estratificados na pirâmide social colonial. Essa dupla relação torna difícil declarar com convicção esses soldados como os primeiros intérpretes oficiais negros do Brasil.

De maneira oficial, no Brasil, tem-se como intérpretes negros os primeiros padres missionários nascidos em terras africanas. Logo que se substituiu o escravizado indígena (s. XVI) pelo escravizado africano, muitos religiosos que se encontravam no Brasil aos poucos foram se "sensibilizando" da necessidade de também evangelizar o africano, e até mesmo postos mais elevados do clero viam na evangelização uma forma de docilizar os cativos, bem como de motivar mais a doação do dízimo da colônia e da metrópole à Igreja (SANTOS, 2008). Entretanto, dois

\footnotetext{
${ }^{21}$ Nome que designa nos séculos XVI e XVII uma espécie de unidade militar ou corpo de tropas do exército português ou/e espanhol.
} 
problemas surgiram: 1) o contingente de negros que chegava ao Brasil era superior a todas as políticas linguísticas produzidas pelos religiosos (formação de catequistas bilíngues, confecção de catecismos, gramáticas e vocabulários bilíngues, etc.) e 2) a formação dos missionários até então estava mais voltada para o par linguístico português-tupi.

Duas alternativas foram encontradas diante deste quadro: a vinda de padres intérpretes africanos e o aproveitamento de padres e colonos brasileiros que aprenderam as línguas africanas pelo convívio com suas amas (SANTOS, 2008). Os padres vindos de Angola ou de Cabo Verde eram, majoritariamente, filhos de portugueses com africanas, e os negros brasileiros, ou mulatos (como eram chamados à época), eram moços da Bahia. Entretanto, essa política de intérpretes religiosos negros ${ }^{22}$ no Brasil durou somente até 1712 (SANTOS, 2008), visto que tal empreendimento não era apoiado por todos os religiosos da Companhia de Jesus no Brasil. Havia entre os religiosos um apoio rigoroso à escravidão e como regra a primazia de pureza europeia do vocacionado.

No século XVIII, com o ciclo do ouro, negros oriundos da Costa da Mina começaram a chegar em maior quantidade no Brasil. Porém, sua proficiência em língua portuguesa era muito baixa. Logo, uma das maneiras encontradas de melhorar a comunicação entre mineradores e negros boçais e também de aculturá-los aos moldes portugueses era a catequização. Novamente, a Companhia de Jesus se encarregou de tal empreitada e, para isso, se utilizou de escravos forros. Formou-os como catequistas bilíngues (SANTOS, 2008). À época, padres também produziram manuais com o intuito de formar catequistas e evangelizadores de negros, e é bem provável que tenham utilizado esses catequistas bilíngues para aprofundar seus conhecimentos linguísticos, bem como revisar e sanar dúvidas durante a feitura dessas obras de referência linguística (gramáticas, glossários, vocabulários, guias de comunicação, etc.).

\footnotetext{
${ }^{22}$ Alguns dados sobre estes intérpretes são sabidos e podem ser consultados no trabalho de SANTOS, 2008, p. 155.
} 
É na virada do século XVIII para o XIX que surge o mais famoso intérprete negro na história brasileira da interpretação. Ele se chama Francisco Félix de Souza (1754-1849), conhecido como Chachá I.

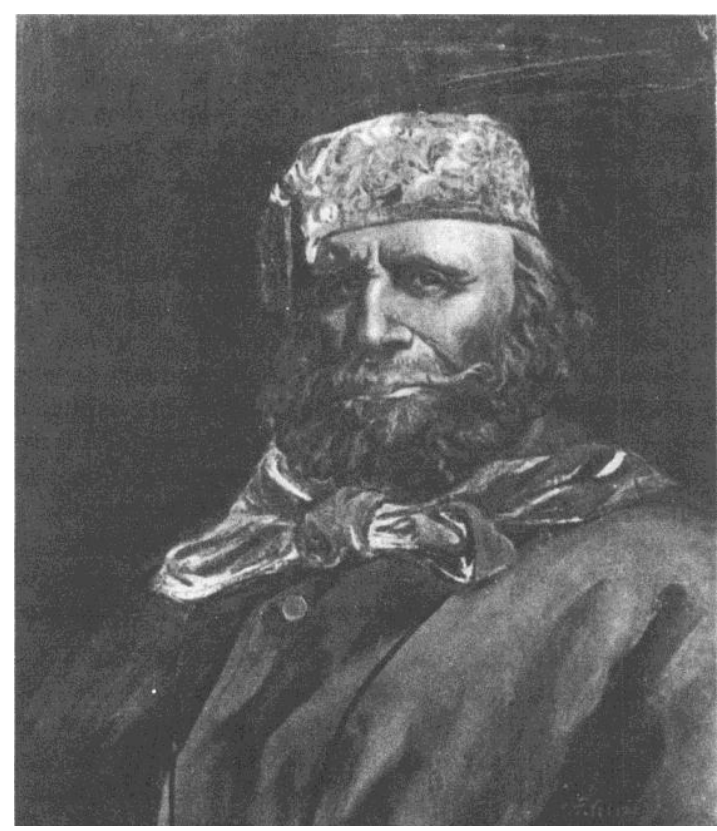

Francisco Félix de Souza. Pintura a óleo de autor desconhecido ${ }^{23}$. Tida como único retrato de Chachá I.

Francisco Félix de Souza nasceu na Bahia e depois morou em Ajudá no atual Benim. "[F]ilho ou neto de português e de índia do Amazonas, que podia ser também uma cabocla ou cafuza. Há quem o diga branco ou o tenha por mulato e com costela escrava. Mulato claro. Ou mestiço indefinido, [...] o mais provável" (SILVA, 2004, p.12). Este baiano mercador de escravos tinha facilidade na aprendizagem de línguas e, apesar de não haver relatos informando em qual língua eram feitas as negociações, o mais provável é que fossem em inglês, francês ou mesmo em português. Segundo Alberto da Costa e Silva (2004, p. 33), seu biógrafo brasileiro,

\footnotetext{
${ }^{23}$ Fonte: <https://pt.wikipedia.org/wiki/FranciscoFélixdeSousa\#/media/File:FranciscoFélixdeSouza.jpg>. Acesso em 23 de julho de 2017.
} 


\begin{abstract}
Ao chegar à África, Francisco Félix só devia comunicar-se em português, mas, como esta era a língua franca do comércio naquela parte da Costa, não tardou em tornar-se, por ter aprendido um ou mais dos falares do grupo gbe, um excelente intermediário de negócios, a serviço tanto dos vendedores nativos quanto dos navios que chegavam do Brasil ou da Europa. É possível também que se tivesse feito rapidamente conhecido e apreciado pela "integridade inflexível e indiscutível" com que "conduzia todas as operações comerciais" de que se encarregava - conforme escreveu um contemporâneo, que tinha tudo para não lhe ser simpático, comandante que era da marinha de guerra britânica, Sir Henry Huntley.
\end{abstract}

De fato, Chachá era casado com a filha de um dadá (nome dado a um rei do Daomé). Este dadá tinha por intuito melhorar a continuação do tráfico de escravos, mercadoria cara em Ajudá (SILVA, 2004). Para isso, contou com seu genro, sabedor de línguas, mas igualmente com ampla experiência em tráfico humano de cativos. Ademais, Francisco Félix de Sousa tinha duas nacionalidades (a brasileira e a portuguesa) e se utilizava deste trunfo quando necessário e oportuno. Intérprete, intermediário e negociante: esses eram os atributos que resumiam seu perfil. Entretanto, o fato que o faz ser mais memorado do que qualquer outro traficante de escravos da época, é o protetorado oferecido por ele a ex-escravos brasileiros que retornaram ao Benim, os agudás ${ }^{24}$.

Além de Chachá I, possivelmente alguns outros crioulos podem ter seguido o mesmo caminho, mas a atuação destes é pouco conhecida. Dois outros grupos de intérpretes negros também são identificados na historiografia brasileira: o intérprete das expedições científicas e o intérprete oficial da polícia. Do primeiro tem-se poucos dados e era um ofício informal ou secundário aos guias negros das expedições. Por sua vez, o segundo aparece em numerosos relatos registrados em documentos da

\footnotetext{
${ }^{24}$ Entre os agudás, Francisco Félix de Souza é reverenciado por ter promovido a existência desta comunidade no Benim. Com o Levante dos Malês (1835), ocorrido na Bahia sob a liderança de exescravos, criou-se um pânico e uma rejeição por negros africanos, o que ocasionou a deportação de inúmeros deles. Ao chegarem na África, esses negros não eram mais reconhecidos como pertencentes às suas comunidades de origem. Contudo, encontraram acolhida e proteção junto a Chachá I, formando, assim, uma comunidade brasileira cultural no Benim (les Brésiliens du Bénin) existente até os dias atuais. Para mais informações sobre o assunto, consultar GURAN, 2000.
} 
época e dispersos nos inúmeros trabalhos de historiadores da diáspora africana e do escravismo no Brasil.

Durante o século XIX, o Brasil recebeu grande número de expedições estrangeiras com o objetivo de fazer um levantamento científico da fauna e flora. Estas expedições tinham como base o desbravamento de terras pouco conhecidas ou mapeadas geograficamente pelos portugueses, o que ocasionou o contato com muitos outros povos existentes no Brasil. A maioria dessas expedições eram guiadas por intermediários (linguísticos e culturais) nativos da terra (indígenas ou não), o que já se demonstrou em trabalho anterior (SILVA-REIS; BAGNO, 2016). Entretanto, fato pouco conhecido é que estes intermediários, vez ou outra, eram também negros. Estes poderiam ter aprendido as línguas dos povos nativos também por imersão - já que conviviam com eles cotidianamente - ou pelo fato de também se relacionarem biologicamente. Também cabe dizer que é muito provável que os cafuzos (ou afro-indígenas) tenham sido também intérpretes no Brasil Colônia e Império, pois a miscigenação foi uma das marcas da formação do povo brasileiro. É claro que isso é apenas uma hipótese levantada neste trabalho, já que fontes históricas nos faltam para fazer tal afirmativa categoricamente.

Um dos relatos de negros intérpretes das expedições foi deixado pelos alemães Johann Baptist von Spix (1781-1826) e Carl Friedrich Philipp von Martius (1794-1868) que estiveram no Brasil no contexto da comitiva da Missão Artística Austro-Alemã (1817-1818). Depois de descrever um ritual de dança e canto dos índios puris, Spix e Martius relatam que

\footnotetext{
"[u]m negro, que viveu muito tempo entre os Puris, nos interpretou aquelas palavras plangentes, cantadas na dança, como lamentação de haver caído quando queriam colher uma flor de uma árvore. A explicação que nos ocorria, diante deste quadro melancólico, era do paraíso perdido" ([1817-1820]1981, p. 50, 54-57).
}

Os dois viajantes estavam acompanhados por um guia (um militar guia-intérprete, mencionado em passagens anteriores deste relato), entretanto, o ato de interpretação realizado durante as "observações 
antropológicas" foi realizado por um negro que lhes fazia entender o que era dito pelos índios puris. Episódios desses intérpretes-guias negros podem ser encontrados em outros relatos de viajantes da época, bem como são expostos em forma figurativa:

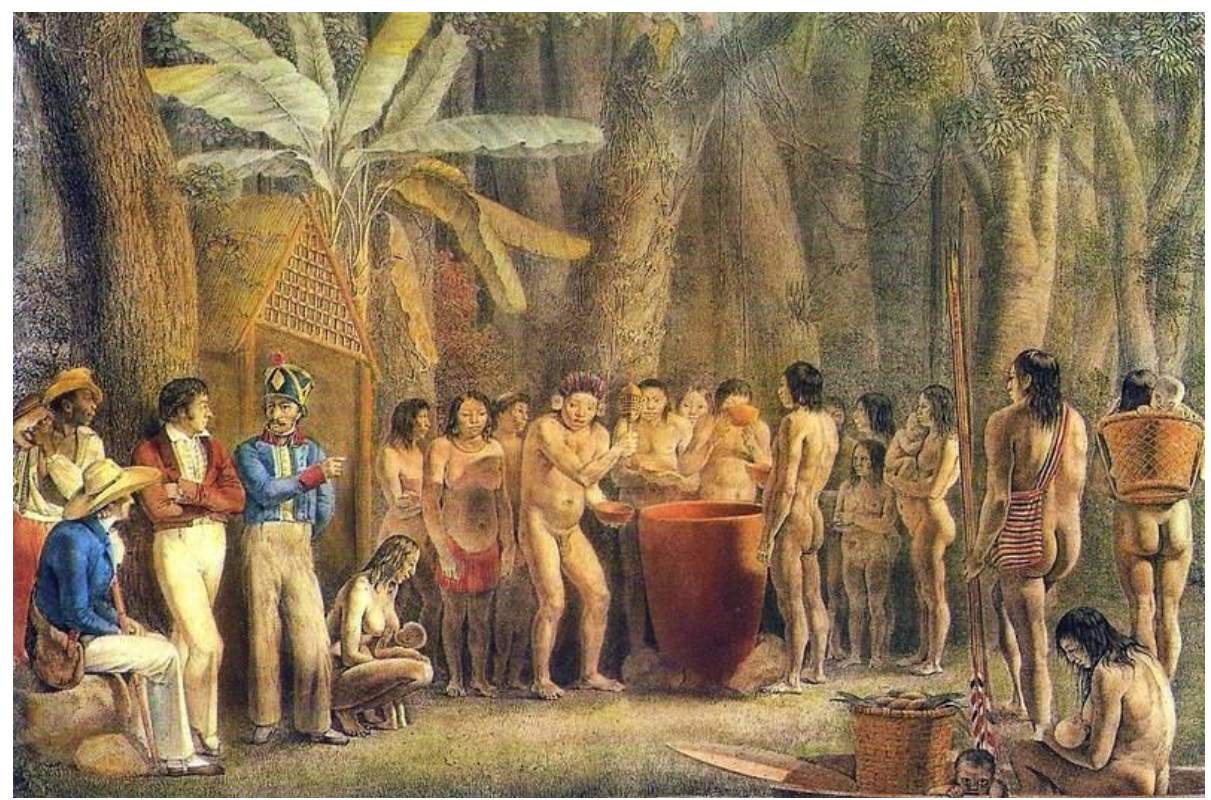

Tanz der Puris (dança dos Puris)25, 1820-1823,

de Johann Baptist Spix (1781-1826) e Carl Friedrich Philipp von Martius (1794-1868)

\footnotetext{
${ }^{25}$ Fonte: < https://pt.wikipedia.org/wiki/Petrópolis\#/media/File:E.Mayer-Festadebeberdoscoroados.JPG >. Acesso em 23 de julho de 2017.
} 


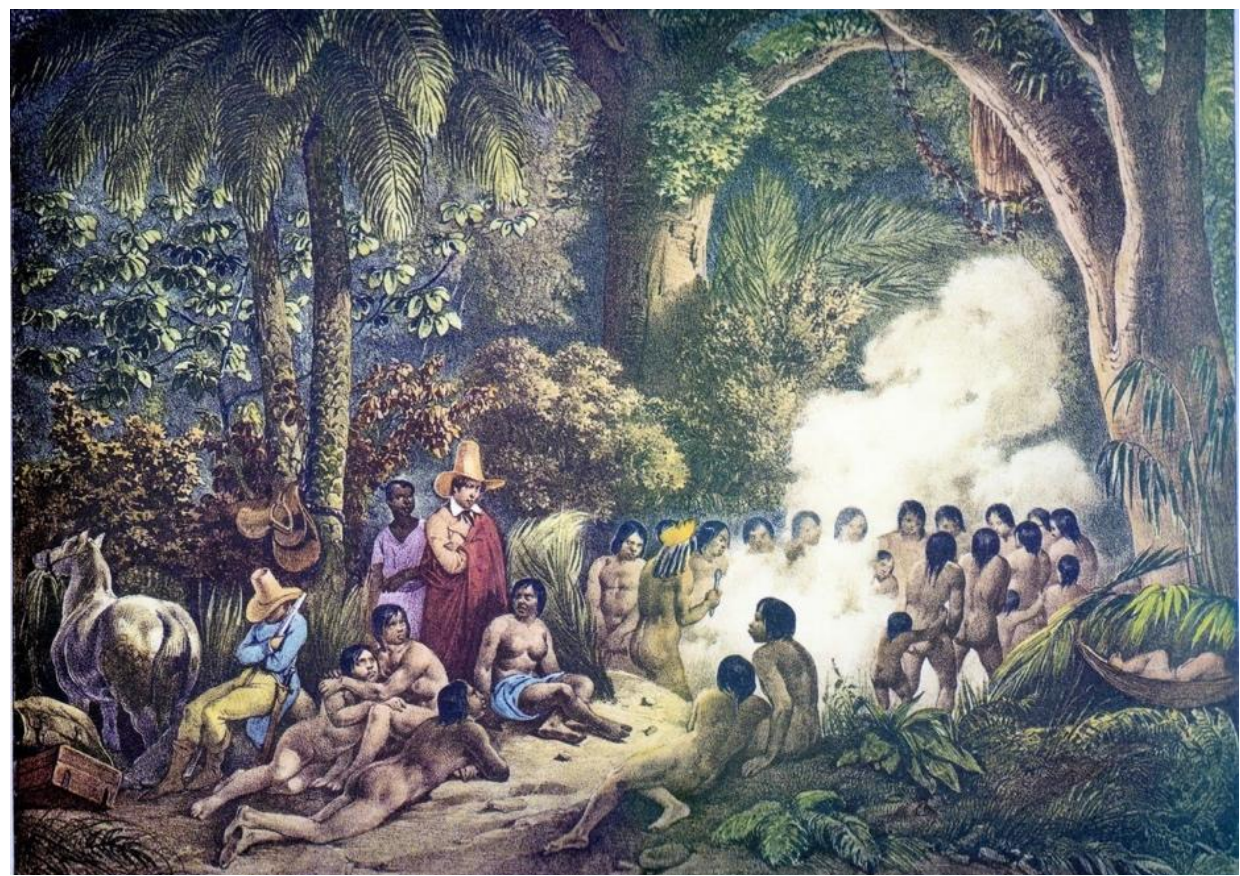

Dança dos Puris (1835) de Johann Moritz Rugendas (1802-1858)

Nas duas litografias históricas, observa-se a figura do intérpreteguia militar, mas igualmente do intérprete negro. São registros pictóricos que visibilizam dentro da iconografia brasileira a história visual da tradução ${ }^{26}$ em que os intérpretes negros se encontram inseridos. Provavelmente a pouca visibilidade desses negros nas litografias apresentadas seja apenas o reflexo da pouca visibilidade de intérpretes negros na história brasileira da tradução oral como um todo ${ }^{27}$.

Em 7 de novembro de 1831, foi decretada uma lei que proibia a entrada de novos escravizados, bem como proibia este tipo de comércio. A

\footnotetext{
${ }^{26}$ Para mais detalhes sobre a iconografia da tradução no século XIX, consultar SILVA-REIS, 2017.

27 Uma outra litogravura que chama bastante atenção é a intitulada Capitão do Mato de 1824 feita por Johann Moritz Rugendas. Esta obra traz dois negros em posições antagônicas: um, perseguidor, outro, fugitivo. A partir desta iconografia, nos questionamos se os capitães do mato eram também intérpretes e se negros ladinos que falassem línguas africanas exerciam mais facilmente esse ofício. A historiadora Silvia Hunold Lara, que estudou a fundo a questão dos capitães do mato (LARA, 1988), esclarece-nos que estes eram pardos ou negros e que era possível sim que falassem alguma língua africana (LARA, 2017), pois havia muitos indícios da necessidade senhorial de os senhores - incluindo os servos dos senhores, como os capitães do mato - entenderem a língua (ou línguas) dos escravos para prevenirem fugas e ajuntamentos (LARA, 2007).
} 
partir desta lei, o volume de tráfico ilegal de negros no Brasil aumentou significativamente, o que fez com que em 12 de abril de 1832 uma lei complementar fosse decretada ditando regras de como a polícia imperial deveria agir diante dos casos. No artigo nono da lei de 1832 está escrito:

Art. $9^{\circ}$ Constando ao Intendente Geral da Policia, ou a qualquer Juiz de Paz, ou Criminal, que alguém comprou ou vendeu preto boçal, o mandará vir à sua presença, examinará se entende a lingua brazileira; se está no Brazil antes de ter cessado o trafico da escravatura, procurando por meo de interprete certificar-se de quando veio d'Africa, em que barco, onde desembarcou, por que lugares passou, em poder de quantas pessoas tem estado, etc. Verificando-se ter vindo depois da cessação do trafico, o fará depositar, e procederá na fórma da Lei, e em todos os casos, serão ouvidas summariamente, sem delongas superfluas as partes interessadas ${ }^{28}$ (grifo nosso).

Percebe-se que por essa lei, mesmo que nas entrelinhas, o ofício de intérprete negro foi oficializado no Brasil no século XIX. O artigo nono é preciso em dizer que tais intérpretes eram necessários para se lidar com negros boçais (não proficientes em língua portuguesa). Mesmo que se possa mencionar que homens brancos tenham exercido tal ofício, pelas pesquisas historiográficas realizadas nesse campo sabe-se que quase a totalidade desses intérpretes de línguas africanas eram negros ladinos (proficientes em português não-nascidos no Brasil), e a dificuldade de se encontrar brancos ou crioulos (negros brasileiros) proficientes nessas línguas era muito grande.

Alguns dados sobre esse tipo de intérprete e seu ofício nos são fornecidos pelo historiador Jaime Rodrigues (1994, p. 218-219):

[...] há o fato de que os africanos apreendidos, sendo boçais, necessitavam de um intérprete para seus depoimentos. Muitas vezes havia dificuldade de se encontrar um intérprete conhecedor da língua específica dos africanos apreendidos, e mesmo quando o interrogatório se fazia com o auxílio de um ladino, ocorre uma repetição no conteúdo dos depoimentos.

\footnotetext{
${ }^{28}$ Legislação Informatizada - DECRETO DE 12 DE ABRIL DE 1832 - Publicação Original. Disponível em: <http://www2.camara.leg.br/legin/fed/decretsn/1824-1899/decreto-37370-12-abril-1832-563951publicacaooriginal-88005-pe.html>. Acesso em 23 de julho de 2017.
} 


\begin{abstract}
Pode-se pensar em algumas hipóteses para essa repetição: os africanos seguiriam as declarações feitas pelo primeiro deles a ser interrogado ou combinariam previamente as respostas entre eles, o que me parece uma possibilidade mais remota. A repetição pode ser creditada ainda ao intérprete ladino, que em alguns casos poderia não reproduzir fielmente as peculiaridades de cada depoimento, ou ao escrivão do processo, que talvez não julgasse necessário ouvir atentamente a tradução do que dizia cada interrogado. No caso dos processos da Auditoria Geral de Marinha, julgados pelo auditor José Batista Lisboa, o interrogatório dos africanos apreendidos foi coletivo, embora isto infringisse a lei, e não houve qualquer observação contrária pelas autoridades que julgavam o processo em segunda instância - o Conselho de Estado.
\end{abstract}

Como se nota, esses intérpretes oficiais negros trabalhavam sempre em conjunto com a polícia ou militares das forças armadas, não eram profissionais fáceis de serem encontrados no mercado de trabalho e sofriam preconceito e desconfiança dos superiores no que tange à qualidade de seu ofício. Observa-se também nos dados oferecido por Rodrigues que, de praxe, esses intérpretes, possivelmente, realizavam a interpretação intermitente ou consecutiva; mas ocorria também e, de forma ilegal, a interpretação coletiva, que não se sabe exatamente como se dava, apesar de parecer uma das modalidades de interpretação praticadas (e, talvez, recorrentes) por esse grupo de intérpretes à época. É importante frisar que não se sabe ainda com detalhes como se dava a seleção desses intérpretes, porém supõe-se que eram, majoritariamente, negros alforriados em busca de trabalho, não importa qual fosse. Sidney Chalhoub (2012), em sua obra A força da escravidão, narra alguns casos desses intérpretes oficiais negros, oferecendo até alguns nomes encontrados nas documentações oficiais de processos de apreensão de embarcações ilegais.

Cabe ainda mencionar que, sendo o século XIX o de maior desenvolvimento social e científico no Brasil (em particular, médico e jurídico), a probabilidade de ter havido intérpretes negros que exerceram a intepretação jurídica e médica é muito grande, dada a existência de políticas de "melhorias" para as populações negras que aqui se encontravam, a utilização de negros como cobaias de experiências sociais e científicas e o tráfico negreiro recorrente e ilegal até final do século. Esses agentes de interpretação, suas histórias e seus registros históricos ainda 
estão dispersos à espera de pesquisadores que os reúnam, os mostrem e os disponham em forma de narrativa historiográfica.

\section{Epílogo}

Os três movimentos aqui operados para elaborar uma historiografia principiante do intérprete negro da diáspora mostraram como este ofício foi exercido na África, em Portugal e no Brasil. Percebe-se que o ofício de intérprete exercido por negros, desde sua origem, sempre foi visto como algo servil e de qualidade duvidosa. Visão esta imposta pelo Outro branco e colonizador europeu - a todos aqueles que não tinham a sua mesma origem. As políticas de interpretação (em particular a formação e o exercício do cargo) para as populações negras existentes no Brasil em nenhum momento foram gratuitas. Tinham como objetivo mascarado o favorecimento de elites brasileiras, políticas de mercado vindas da Europa como a Revolução Industrial, e a manutenção de um sistema escravocrata centralizador e organizado. Daí, tem-se uma explicação da secundarização deste ofício ou mesmo da combinação de outras profissões (guia, marinheiro, negociador, etc.) com a função de intérprete.

É visível igualmente que o imaginário historiográfico (escrito e figurativo) de intérpretes (indígena, negro e branco) ainda está pautado por perfis masculinos, geralmente, homens adultos. Porém, pelos dados apresentados na presente pesquisa, vê-se o papel essencial que mulheres tiveram como intermediárias linguísticas e culturais no triângulo geográfico aqui estudado (Portugal-África-Brasil). Apesar disso, pouco se escreveu ou ainda se sabe sobre quem eram essas mulheres. Uma memória apagada que ainda precisa vir à tona. Somam-se a mulheres indígenas também as mulheres negras que são, majoritariamente, esquecidas como intermediárias na tímida historiografia da tradução no Brasil.

O recorte socioétnico desta pesquisa historiográfica confirma uma vez mais a especificidade do domínio dos Estudos da Tradução e diásporas negras - posicionamento defendido em trabalhos anteriores (SILVA-REIS, AMORIM 2016; SILVA-REIS, ARAÚJO, 2017). Como demonstramos ao longo deste ensaio, não há somente uma história negra a ser narrativizada e rememorada, mas igualmente uma identidade do ser negro como 
intérprete/tradutor mediada pela historiografia com ênfase na apresentação de personagens e eventos, consolidação de noções metalinguísticas da história da tradução oral - intérprete ladino, grumete, tangoma, turgimania, etc. - e uma iconografia da tradução própria a este grupo específico. Esta pesquisa é apenas o início de um campo historiográfico pouco explorado nos Estudos da Tradução no Brasil. A história das complexas relações socioétnicas que envolvem as populações negras e a história da interpretação ainda tem muitos caminhos a serem trilhados por exemplo, Yeda Pessoa de Castro (2002) menciona o caso de Antônio da Costa Peixoto, um "branco ladino" que sabia a língua dos negros em Vila Rica (séc. XVIII), e Ivana Stolze Lima (2013) relata o caso de Pedro Dias, jesuíta do século XVII, proficiente em uma língua veicular africana, o que nos faz conjecturar que possam ter existido outros tradutores e intérpretes com o mesmo perfil. Por quê? Para quê? Onde? são apenas alguns dos questionamentos ainda sem resposta para esses casos à espera de estudos.

Em suma, o grande benefício da pesquisa historiográfica para os estudos de interpretação é a criação ou manutenção de uma cultura da tradução/interpretação. É essa base cultural que faz com que o ofício da tradução e da interpretação tenha uma tradição e solidez no espaço e tempo dos diferentes povos e regiões geográficas. É pela cultura da tradução/interpretação que é possível observar sua evolução, pertinência e âmbito particular. É observando o passado que se buscam melhorias jurídicas, éticas, políticas e sociais para essa categoria profissional, mas igualmente observando o passado é que se explica, em grande parte, o estágio atual do ofício de intérprete no Brasil para pessoas negras. Talvez seja necessário olhar mais o passado para saber reconhecer os resquícios do colonialismo português a fim de se alcançar uma consciência histórica, que é, nas palavras de Jörn Rüsen (2010, p. 104), “a constituição de sentido sobre a experiência do tempo, no modo de uma memória que vai além dos limites da sua própria vida prática". 


\section{Referências ${ }^{29}$}

ALMEIDA, M. A. L.. “As Vozes Centro-Africanas no Atlântico Sul (1831c.1850). In: LIMA, I. L.; CARMO, Laura. (Orgs.). História Social da Língua Nacional 2: Diáspora Africana. 1ed. Rio de Janeiro: Nau/Faperj, 2014.

---------. Ladinos e Boçais: o regime de línguas do contrabando de africanos (1831-c.1850). 200p. Dissertação (Mestrado em História). Pósgraduação em História. Universidade Estadual de Campinas, São Paulo, 2012.

ALVES, A. Dicionário de Arabismos da Língua Portuguesa. Lisboa: Imprensa Nacional - Casa da Moeda. S. A., 2013.

BAQUAQUA, M. G.. Biografia de Mahommah Gardo Baquaqua : um nativo de Zoogoo, no interior da África. Tradução de Lucciani M. Furtado. São Paulo: Uirapuru, 2017.

BARBOSA, H. G. Caminhos e descaminhos dos estudos da tradução e interpretação no Brasil. Trama, v. 5, n. 9, p. 27-47, 2009.

BARROS, M. C. D. M.; MARUYAMA, T.. “O perfil dos intérpretes da Companhia de Jesus no Japão e no Brasil no século XVI". Revista Fênix: Revista de História e Estudos Culturais. v.4, a.4, n.4. Uberlândia: Faculdade Federal de Uberlândia, 2007.

BARROS, M. C. D. M.. “Intérpretes e confessionários como expressões de políticas linguísticas da Igreja voltadas à confissão". DELTA. Documentação de Estudos em Linguística Teórica e Aplicada v. 27, n. 2. São Paulo: PUCSP, 2011.

. “O intérprete jesuíta na constituição de um Tupi supra-étnico no século XVI". Papia, v. 3 n. 2. Brasília, 1994.

- “Os Intérpretes Jesuítas Como Fonte de Estudo da Situação Colonial". In: Marília Facó. (Org.). Estudos da linguagem: limites e espaços. 1ed. Rio de Janeiro: UFRJ, 1997.

BENJAMIN, N. L.; OSBORN, E. L.; ROBERTS, R. L. (orgs.). 2006. Intermediaries, Interpreters, and Clerks. African Employees in the Making of Colonial Africa. Madison: University of Wisconsin Press, 2006.

\footnotetext{
${ }^{29}$ Agradeço imensamente à professora e historiadora Silvia Hunold Lara pelas gratas indicações bibliográficas, bem como pelo envio de fontes históricas enriquecedoras deste trabalho.
} 
CADAMOSTO, Luis. Viagens de Cadamosto e de Pedro Sintra. Tradução de João Franco Machado. Prefácio e notas de Damião Peres. Lisboa: Academia Portuguesa de História,1948.

CAMPBELL, A. S.. “Tradutores Públicos e Traduções Juramentadas no Brasil". In: PORTINHO, W. M. (Org.). A tradução técnica e seus problemas. São Paulo: Álamo, 1984.

PARÉS, L. N. (org.). “Cartas do Daomé: uma introdução”. In: Revista AfroÁsia. Salvador, n. 47,2013.

CARVALHO, F. A. L.. “Mediadores do sagrado: os auxiliares indígenas dos missionários nas reduções jesuíticas da Amazônia ocidental (c. 1638-1767)". Revista de História. N. 173. São Paulo: USP, 2015.

Lealdades negociadas: povos indígenas e a expansão dos impérios ibéricos nas regiões centrais da América do Sul (segunda metade do século XVIII). 595p. Tese (Doutorado em História). Pós-graduação em História Econômica. Universidade Estadual de São Paulo, São Paulo, 2012.

CARVALHO, F. M.. "Ngolas, sobas, tandalas e macotas: hierarquia e distribição de poer no antigo reino do Ndongo". In: RIBEIRO, A.; GEBARA, A.; BITTENCOURT, M. (orgs). África passado e presente: II encontro de estudos africanos da UFF [recurso eletrônico]- Niterói: PPGHISTÓRIA-UFF, 2010.

. Os Homens do rei em Angola: sobas, governadores, capitães mores, séculos XVII e XVIII. 2013. 285 p. Tese (Doutorado em História) Pós-graduação em História. Universidade Federal Fluminense, Niterói Rio de Janeiro, 2013.

CASTRO, Y. P.. “A língua mina-jeje no Brasil, uma língua negro-africana documentada em Vila Rica no século XVIII". In: LIMA, I. L.; CARMO, Laura. (Orgs.). História Social da Língua Nacional 2: Diáspora Africana. 1ed. Rio de Janeiro: Nau/Faperj, 2014.

. A língua Mina-jeje no Brasil: um falar africano em Outro Preto do século XVIII. Belo Horizonte: Fundação João Pinheiro/ Secretaria de Estado da Cultura, 2002.

. Falares africanos na Bahia : um vocabulário afro-brasileiro. Rio de Janeiro: Academia Brasileira de Letras, 2005. 
CAVALLO, P.; REUILLARD, P. C. R.. "Estudos da Interpretação: tendências atuais da pesquisa brasileira”. Letras \& Letras. V. 36. N.1. Uberlândia: UFU, 2016.

CHALHOUB, S.. A força da escravidão: ilegalidade e costume no Brasil oitocentista. São Paulo: Companhia das Letras, 2012.

COUTO, D.. “O papel dos Intérpretes ou Línguas no Império Português do Século XVI". HELB - História do Ensino de Língua no Brasil. Ano 5. N. 5. Tradução de José C. P. Almeida Filho e Júlia M. A. Barros. Brasília: Universidade de Brasília: 2011.

CRONIN, M. "The Empire Talks Back: Orality, Heteronomy, and the Cultural Turn in Interpreting Studies”. In: TYMOCZKO, M.; GENTZLER, E.. Translation and Power. Amherst and Boston: University of Massachusetts Press, 2002.

DECRETO DE 12 DE ABRIL DE 1832 - Publicação Original. Disponível em: <http://www2.camara.leg.br/legin/fed/decretsn/1824-1899/decreto37370-12-abril-1832-563951-publicacaooriginal-88005-pe.html>. Acesso em 23 de julho de 2017.

DELISLE, J.; WOODSWORTH, J. Os Tradutores na História. Tradução: Sérgio Bath. São Paulo: Editora Ática, 1998.

. "Les interprètes français au Brésil au xvie siècle" In: Le Linguiste

De Taalkundigi. n. 1-2. Bruxelles: Organe de la Chambre Belge des Traducteur, 1977.

. "Introduction". In: ROLAND, R. Interpreters as Diplomats. Ottawa, University of Ottawa Press, 1999.

. "Jacques Cartier's Interpreter" The Jerome Quarterly. v. 9, n. 2. Washington: National Resource Center for Translation \& Interpretation, 1993.

. “Le sens à travers l'histoire de la traduction : de l'Antiquité au xixe siècle". In: ISRAEL, F.; LEDERER, M. (orgs.). La théorie interprétative de la traduction: convergences, mises en perspective. T. 2. Paris: Minard, 2005.

. “Les pionniers de l'interprétation au Canada". Meta, v. 22, n. 1. Montreal: Presses de l'Université de Montreal, 1977.

La traduction au Canada / Translation in Canada, 1534-1984. Ottawa: Presses de l'Université d'Ottawa, 1987. 
GARANE, J. "The Invisibility of the African Interpreter". $A$ Transdisciplinary Journal. Issue 5. Misano Adriatico - Itália: Nida School of Translation Studies, 2015.

GINEZI, L. L.. “A ética na interpretação de tribunal: o Brasil no banco dos réus". Tradterm, v. 20. São Paulo: Universidade de São Paulo, 2012.

GUERINI, A.; COSTA, W. C.; TORRES, M-H.. Os Estudos da Tradução no Brasil nos séculos XX e XXI. Tubarão: Ed. Copiart; Florianópolis: PEGET/UFSC, 2013.

GURAN, M. Agudás: os brasileiros do Benim. Rio de Janeiro: Nova Fronteira, 2000.

ITO, A. I.. “Uma 'tão pesada cruz': o governo da Angola portuguesa nos séculos XVI e XVII na perspectiva de Fernão de Sousa (1624-1630). 2016. 408p. Dissertação (Mestrado em História) - Pós-graduação em História Social. Universidade de São Paulo, São Paulo, 2016.

JULIO, S. S.. Damiana da Cunha: uma índia entre a "sombra da cruz" e os caiapós do sertão (Goiás, c 1780-1831). 171p. Dissertação (Mestrado em História). Pós-graduação em História. Universidade Federal Fluminense, Niterói, 2015.

LARA, S. H.. Campos da violência: escravos e senhores na Capitania do Rio de Janeiro (1750-1808). Rio de Janeiro: Paz e Terra, 1988.

Legislação sobre escravos africanos na América Portuguesa. In: ANDRÉS-GALLEGO, Jose (Coord). Nuevas Aportaciones a la Historia Jurídica de Iberoamérica. Madrid: Fundación Histórica Tavera/Digibis/Fundación Hernando de Larramendi, 2000 (CD-Rom). - “Linguagem, domínio senhorial e identidade étnica nas Minas Gerais de meados do século XVIII". In: BASTOS, C.; ALMEIDA, M. V.; FELDMAN-BIANCO, B; (Orgs.). Trânsitos Coloniais: diálogos críticos luso-brasileiros. Lisboa: Imprensa de Ciências Sociais, 2002.

Palmares \& Cucaú: o aprendizado da Dominação. Tese para concurso de professor Titular. Área de História do Brasil. Instituto de Filosofia e Ciências Humanas/Departamento de História. Campinas: Universidade Estadual de Campinas, 2008.

Re: Dúvida sobre capitão do mato. E-mail de 15 de setembro de 2017. 
LIENHARD, M.. “Milonga: o 'diálogo' entre portugueses e africanos nas guerras do Congo e de Angola (séculos XVI-XVII)". In: LIENHARD, M.. O mar e o mato: histórias da escravidão. Luanda: edotorial Kilombelombe, 2005.

LIMA, I. L. “Na Bahia, a arte da língua de Angola. Comunidades linguísticas no mundo atlântico". In: Anais do XXVII Simpósio Nacional de História. Conhecimento histórico e diálogo social. Natal: ANPHUH, 2013.

. "Práticas e fronteiras: africanos, descendentes e língua nacional no Rio de Janeiro". In: LIMA, I. L.; CARMO, Laura. (Orgs.). História Social da Língua Nacional 2: Diáspora Africana. 1ed. Rio de Janeiro: Nau/Faperj, 2014.

MARIANI, B.. Quando as línguas eram corpos - sobre a colonização linguística portuguesa na África e no Brasil. In: Orlandi, E. P.. Política linguística no Brasil. Campinas: Pontes Editora, 2007.

MARTINS, M. A. P. “A institucionalização da tradução no Brasil: o caso da PUC-RIO". Cadernos de Tradução. v.1. Florianópolis: Universidade de Santa Catarina, 2007.

MATOS, C. N.. “Textualidades indígenas". In: FIGUEIREIDO, Euridíce (org.). Conceitos de Literatura e Cultura. 2ed. Rio de janeiro: EDUFF, 2012.

METCALF, A. C.. "A busca pelo intermediário feminino no século 16 no Brasil". In: SCHWARTS, S.; MYRUP, E. L. (orgs.). O Brasil no Império marítimo português. Bauru-SP: Edusc, 2009a.

. "A mulher como intermediária: estudos de caso de história e de literatura”. In: MORGA, A. E.; BARRETO, C. M.. Gênero, sociabilidade e afetividade. Itajaí: Casa Aberta, 2009b.

Go-Betweens and the Colonization of Brazil. Austrin: The University of Texas Press, 2005.

MATTOS, H.. “Da guerra preta às hierarquias de cor no Atlântico Português". In: Anais Complementares do XXIV Simpósio Nacional de História. História e Multidisciplinaridade: territórios e deslocamentos. São Leopoldo: Associação Nacional de História - ANPUH, 2007. 
MULLENDER, G. The importance of interpreting during the Portuguese discoveries in Africa and Asia. 261p. Tese (Doutorado em Estudos Comparatistas). Programa de Estudos Comparatistas. Lisboa: Universidade de Lisboa, 2015.

NAMA, C. A. "A history of translation and interpretation in Cameroon from precolonial times to present". Meta. V. 35. N.2. Montreal: Presses de l’Université de Montreal, 1990.

NIANG, Anna. "History and Role of Interpreting in Africa". In: BOWEN, D.; BOWEN, M. (orgs.). Interpreting: Yesterday, Today, and Tomorrow. Binghamton: State University of New York Press, 1990.

OLIVEIRA, L. E. M. de. A instituição do ensino das Línguas Vivas no Brasil: o caso da Língua Inglesa (1809-1890). 378p. Tese (Doutorado em Educação). Programa de Estudos Pós-Graduados em Educação: História, Política, Sociedade. Pontifícia Universidade Católica de São Paulo, 2006.

. "As origens da profissão de tradutor público e intérprete comercial no Brasil (1808 - 1943)". In: Claritas: Revista do Departamento de Inglês da Pontifícia Universidade Católica de São Paulo, 2005.

ORIGUELA, D._A.. "Interpretação comunitária, direitos humanos e assistência social: proposta de política pública no contexto brasileiro". Tradterm, v. 23. São Paulo: Universidade de São Paulo, 2014.

PAGURA, R. J.. "Conference Interpreting in Brazil: A Brief Historical Overview and Some Future Trends". Anglo-Saxónica. Revista do Centro de Estudos Anglísticos da Universidade de Lisboa, v. III. Lisboa: Universidade de Lisboa, 2012.

. A interpretação de conferências no Brasil: história de sua prática profissional e a formação de intérpretes brasileiros. 116p. Tese (Doutorado em Letras). Pós-Graduação em Estudos Linguísticos e Literários do Inglês. Universidade de São Paulo, São Paulo, 2010.

PAIVA, M. M. G. “Mediadores Linguísticos e Culturais: O 1.ํ Regimento do Língua da Cidade de Macau". Administração : revista de administração pública de Macau. - N. 994, vol. XXIV. Macau: A. P.M., 2011. PERRONE-MOISÉS, B.. “Franceses no Maranhão: Histórias de Intérpretes". In: PERRONE-MOISÉS, L.. (Org.). Cinco Séculos de Presença Francesa no Brasil. 1ed. São Paulo, SP: EDUSP, 2013. 
PINHEIRO, C. C.. “Língua e conquista: Formação de intérpretes e políticas imperiais portuguesas de comunicação em Ásia nos alvores da modernidade". In: LIMA, I. L.; CARMO, Laura. (Orgs.). História Social da Língua Nacional. 1ed. Rio de Janeiro: Fundação Casa de Rui Barbosa, 2008. Traduzindo mundos, inventando um império: língua, escravidão e contextos coloniais portugueses dos alvores da Modernidade. Tese. 227 p. (Doutorado em Antropologia Social). Pós-graduação em Antropologia Social. Universidade Federal do Rio de Janeiro, Rio de Janeiro, 2005.

PRATA, A. B. A.. O papel da formação em interpretação dos tradutores públicos e intérpretes comerciais no estado do Ceará. 167p. Dissertação (Mestrado em Estudos da Tradução). Pós-Graduação em Estudos da Tradução. Fortaleza: Universidade Federal do Ceará, 2017.

QUEIROZ, M.. "Panorama da interpretação em contextos médicos no Brasil: perspectivas". Tradterm, v. 23. São Paulo: Universidade de São Paulo, 2014.

Interpretação Médica no Brasil. 136 p. Dissertação (Mestrado em Estudos da Tradução). Pós-Graduação em Estudos da Tradução. Florianópolis: Universidade Federal de Santa Catarina, 2011.

RODRIGUES, J.. De costa a Costa: escravos e tripulantes no tráfico negreiro (Angola - Rio de Janeiro, 1780-1860). 426 p. Tese (Doutorado em História). Pós-graduação em História. Universidade Estadual de Campinas, São Paulo, 2000.

. O Infame Comércio: Propostas e experiências no final do tráfico de africanos para o Brasil (1800-1850). 286 p. Dissertação (Mestrado em História) Pós-graduação em História. Universidade Estadual de Campinas, São Paulo, 1994.

ROMÃO, T. L. C.. "Aspectos históricos e práticos de interpretação". Revista de Letras. N. 20, v. 1/2. Fortaleza: Universidade Federal do Ceará, 1998.

RÜSEN, Jörn. História Viva - Teoria da História III: formas e funções do conhecimento histórico. Tradução Estevão de Rezende Martins. Brasília: UnB, 2010.

SANTOS, V. S.. As bolsas de mandinga no espaço Atlântico: Século XVIII. 255p. Tese. (Doutorado em História). Pós-graduação em História Social. Universidade de São Paulo, São Paulo, 2008. 
SCHUMAHER, S.; BRAZIL, E. V. Mulheres negras do Brasil. REDEH/A gente se fala: 2006.

SILVA-REIS, D.. “História Visual da Tradução: a iconografia do século XIX no Brasil". In: Domínios de Lingu@gem. V. 11. N. 5. Uberlândia: Universidade Federal de Uberlândia, 2017.

; AMORIM, L. M.. “Negritude e tradução no Brasil: o legado do Barão de Jacuecanga". Cadernos de Literatura em Tradução. n. 16. São Paulo: Universidade de São Paulo, 2016.

; ARAÚJO, C. G. S.. “Tradução e Diásporas Negras: o percurso da graúna metafísica". TRANSLATIO, n. 13. Porto Alegre: Universidade Federal do Rio Grande do Sul, 2017.

; BAGNO, M.. "Os intérpretes e a formação do Brasil: os quatro primeiros séculos de uma história esquecida". Cadernos de Tradução. V. 36. N. 3. Florianópolis: Universidade de Santa Catarina, 2016.

SILVA, A. C.. A manilha e o libambo: a África e a escravidão, de 1500 a 1700. 2 ed. Rio de janeiro: Nova Fronteira, 2011.

Francisco Félix de Souza, mercador de escravos. Rio de janeiro: Nova Fronteira/EDERJ, 2004.

SILVA, C. S. V. S.. "Poder e Fidelidade na Interpretação". Tradterm, v. 23. São Paulo: Universidade de São Paulo, 2014.

Questões de poder e ideologia nos estudos e na prática da interpretação. Dissertação (Mestrado em Estudos da Linguagem). Pós-Graduação em Estudos da Linguagem. Rio de Janeiro: PUC-Rio, 2013.

SOARES, M. J.. “Para uma compreensão dos Lançados nos Rios de Guiné: século XVI-meados do século XVII". Stvdia, n. 56/57. Lisboa: Centro de Estudos Históricos Ultramarinos, 2000.

SPIX, J. B. V.; MARTIUS, C. F. Ph. Von. Viagem pelo brasil 1817-1820. V1. Tradução Lúcia Furquim Lahmeyer. São Paulo: EDUSP, 1981.

TELES, M. A. A. Breve história do feminismo no Brasil. São Paulo: Brasiliense, 1999.

WYLER, L.. Línguas, poetas e bacharéis: uma crônica da tradução no Brasil. Rio de Janeiro: Rocco, 2003. 
ZERON, C. A.. "Pombeiros e Tangomãos, intermediários do tráfico de escravos na África - século XVI". In: II Colóquio Internacional sobre mediadores culturais. Lagos: Centro de Estudos Gil Eanes, 1999.

\section{Resumo}

O presente ensaio é um esboço da história dos intérpretes negros no Brasil, segundo três movimentos: o primeiro delineia a tradição africana na Idade Moderna; o segundo explora a concepção de intérprete no Império português, e o terceiro mapeia o ofício de intérprete exercido por negros no Brasil Colônia e no Brasil Império. Trata-se de um recorte historiográfico socioétnico que investiga a formação de identidade de intérpretes negros no tempo e no espaço.

Palavras-chave: Intérprete negro; história da interpretação no Brasil; historiografia socioétnica; cultura de tradução; história do Brasil

\footnotetext{
Abstract

This essay attempts to trace a history of black interpreters in Brazil, in three moments. The first explores African tradition during Modern Age. The second addresses the concept of interpreter in the Portuguese empire. And the third maps the work of interpreters of African descent in colonial and imperial Brazil. I aim to provide a historiographical and socio-ethnical narrative that investigates the formation of identity of black interpreters in time and space.

Keywords: Black interpreters; history of interpreting in Brazil; socio-ethnical historiography; culture of translation; history of Brazil.
} 